James Madison University

JMU Scholarly Commons

Fall 11-10-2019

\title{
Librarian, Faculty, and Student Perceptions of Academic Librarians: Study Introduction and Literature Review
}

Jody C. Fagan

James Madison University, faganjc@jmu.edu

Hillary Ostermiller

James Madison University, ostermhc@jmu.edu

Elizabeth Price

James Madison University, price2el@jmu.edu

Lara Sapp

James Madison University, sapple@jmu.edu

Follow this and additional works at: https://commons.lib.jmu.edu/letfspubs

Part of the Library and Information Science Commons

\section{Recommended Citation}

Fagan, Jody C.; Ostermiller, Hillary; Price, Elizabeth; and Sapp, Lara, "Librarian, Faculty, and Student Perceptions of Academic Librarians: Study Introduction and Literature Review" (2019). Libraries. 180. https://commons.lib.jmu.edu/letfspubs/180

This Article is brought to you for free and open access by the Libraries at JMU Scholarly Commons. It has been accepted for inclusion in Libraries by an authorized administrator of JMU Scholarly Commons. For more information, please contact dc_admin@jmu.edu. 


\title{
Librarian, Faculty, and Student Perceptions of Academic Librarians: Study Introduction and Literature Review \\ Jody Condit Fagan, Hillary Ostermiller, Elizabeth Price \& Lara Sapp \\ James Madison University
}

\author{
Author Note \\ JMU Libraries, James Madison University, Harrisonburg, VA 22807 \\ faganjc@jmu.edu; ostermhe@jmu.edu; price2el@jmu.edu; sapple@jmu.edu
}

This is an Accepted Manuscript of an article published by Taylor \& Francis in the journal New Review of Academic Librarianship on November 10, 2019, available online: https://www.tandfonline.com/doi/full/10.1080/13614533.2019.1691026 
A survey concerning perceptions of academic librarians was conducted at a large, 4-year university with three populations: librarians, faculty, and undergraduate students. The high response rate and the use of an instrument based on previous studies offers the possibility of longitudinal comparison and the identification of relationships between groups within one environment. Results will be presented in a series of articles, beginning with this paper's study introduction and literature review of librarian, faculty, and student perceptions of librarians. Subsequent papers will present results from the three surveys and offer analysis across the three groups. The literature review focused on research studies of U.S. and Canadian academic libraries since 2000 with relevance to these major research questions: perceptions about what librarians know (expertise and skills), what librarians do (role and duties), and what librarians are like (motivations and affective behaviours). Librarians' perceptions of themselves as critically important yet underappreciated seem to have persisted, perhaps because they are the only group to see the university-wide scope of their jobs, whereas, non-librarian faculty and students have a more limited views of the profession. In contrast to previous studies, recent literature suggests that course-integrated information literacy (IL) instruction has increased the visibility of librarians as educators to both faculty and students. The influence of popular media on students’ perceptions seems less powerful, opening the door wider for library marketing and branding programs.

Keywords: academic librarians, perceptions, stereotypes, faculty, students, higher education 


\section{Librarian, Faculty, and Student Perceptions of Academic Librarians: \\ Study Introduction and Literature Review}

\section{Context for the Overall Study}

Librarians have a longstanding curiosity about perceptions of themselves and of the profession. While it could be easy to dismiss this interest as ego-centric, frivolous, or even damaging (Jennings, 2016), the profession has changed in some ways for the better as a result of self-reflection. Holley (1976) and Liestman (2003) described how $19^{\text {th }}$-century librarians envisioned a change from being 'caretakers of books' into educators and collection promoters (p. 28), and how these librarians’ reflections helped technological efficiency avoid reducing the profession's humanity. In the $20^{\text {th }}$ century, librarians felt compelled to professionalize in order to increase respect, funding, standardisation, teamwork, and succession planning (Liestman, 2003, p. 41). The attention on who librarians are and what they do has not diminished, as there continues to be an extensive amount of literature regarding librarian images and stereotypes (Pagowsky \& DeFrain, 2014; Posner, 2003; Kneale, 2009; Radford \& Radford, 2001; Vassilakaki \& Moniarou-Papaconstantinou, 2014). The subject also has grown new dimensions as modern society grapples with questions of identity, equitability, and the changing information landscape (Scherdin, 1994).

Due to rapid technological and social change, the profession is evolving. The profession needs to attract and recruit new librarians with the diversity and expertise necessary for the decades ahead (David \& Scherdin, 1994; Delacroix, 1994). The profession needs to actively and consistently describe and promote library expertise and services because they might not always be obvious to users. To be included in strategic decision-making and ensure sufficient funding, librarians must illustrate their value to their campus communities. 
All libraries and librarians contribute toward the professional image of librarians, but each type of library has its own peculiarities. Academic librarians deal with issues relevant to the postsecondary education environment, including college students’ needs, faculty status, teaching, research skills, and subject expertise. Academic librarians also often have relationships with other college faculty and administrators. They might have responsibilities linked to academic subjects and act as liaison librarians who are assigned to academic departments. Depending on the institutional mission, academic librarians might have tenure-track responsibilities or serve as educational technology experts.

Academic librarians need to be perceived as approachable by patrons to teach information literacy (IL) skills effectively and to learn more from them in order to improve services and collections. Librarians need to be seen as educational partners by non-librarian faculty and administrators so they can be involved in strategic planning, connected to relevant campus groups, and supported in tenure and promotion where applicable. They also need to offer input to library and information science programs that are developing curricula for the next student cohort. These dimensions are all relevant to an individual's practice of librarianship, to the local library setting, and to the profession. An individual must grapple with how they are perceived during a presentation to campus administrators or during a reference interaction. A library must define its brand on campus, which includes the perception of its librarians. Professional organisations must advocate for policies and initiatives that move the profession forward on emerging challenges.

To update and expand understanding of the perceptions of academic librarians and their roles, a research team engaged in a survey-based study of librarians, faculty, and students concerning ideas about librarians at a master’s comprehensive university. By gathering 
perspectives from different library constituents using variations of the same instrument, the team hopes to provide new information about differences in perceptions within the same environment. The team used many items from previous instruments so that a longitudinal comparison could be conducted. The sample population included just one library, permitting the researchers to garner adequate sample sizes and enabling the identification of relationships between the librarians, faculty, and students within one environment.

This paper presents the context for the overall study and a literature review for librarian, faculty, and student perceptions of librarians. Subsequent papers will present results from the three surveys and offer analysis across the three groups.

\section{Literature Review}

The literature related to perceptions of librarians and their work is vast (Table 1). Approaches to the topic have included media reviews, personal reflections, surveys, interviews, examinations of librarian photographs and videos images, salary studies, and job profiles.

This literature review will focus specifically on research studies of U.S. and Canadian academic libraries since 2000 with relevance to these major research questions: perceptions about what librarians know (expertise and skills), what librarians do (role and duties), and what librarians are like (motivations and affective behaviours). Search strategies are provided in (Table 2). The following three sections present literature about librarian perceptions, faculty perceptions, and student perceptions, followed by a thematic analysis. 


\section{Literature on Librarian Perceptions of Librarians}

Only a handful of studies were found directly concerning academic librarians’ perceptions of themselves, and some focused on specific aspects or included academic librarians only as a subgroup. The absence of research about librarians’ perceptions of themselves also was noted by Walter (2008) and Vassilakaki and Moniarou-Papaconstantinou (2015).

Librarians are challenged by multiple layers of perceptions, most notably those of gender, race, and sexuality. While these aspects do not always arise in studies of academic librarians, they do in the general perceptions literature. Several scholars have noted that librarianship’s status as a feminine, service-oriented profession results in less social recognition and pay (Christiansen, Stombler, \& Thaxton, 2004; Gaines, 2014). Sexist stereotypes often contain implications of incompetence, and might emphasise presumed natural talents of women, such as 'ability to mother,' 'ability to organise,' and sexuality—while downplaying skill, intellect, or technical ability (Gaines, 2014). Since Carmichael’s article published in 1992, there has not been much research concerning perceptions about male librarians or the perspectives of male librarians themselves (a notable exception being Davis-Kendrick’s (2009) study of AfricanAmerican male librarians). Perceptions and experiences of librarians from minority groups have been found to be distinct from non-minority groups (Alabi, 2015; Thornton, 2000), and an exploratory study found academic librarians to have varying perceptions of themselves based on generational stereotypes (Hayes, Parks, McNeilly, \& Johnson, 2018). Additional research is needed from the perspective of librarians from under-represented populations. What Librarians Know: Librarian Expertise and Skills / Value for Librarians’ Skills

One place that academic librarians express their opinions about the critical expertise and skill for their work is in job advertisements (Table 3). While the MLS is still usually considered 
essential (Gerolimos, Malliari, \& Iakovidis, 2015), it is less frequently required than it was in the past (Grimes \& Grimes, 2008). Some core skills have appeared consistently over time:

communication skills, technology skills, library science skills, flexibility, and the ability to work independently (Gerolimos, Malliari, \& Iakovidis, 2015; Goetsch, 2008). Specific skills and domains such as licensing work, open access support, systems integration skills, social media skills, and scholarly communication knowledge are becoming more common (Goetsch, 2008). The bevy of job advertisement content analyses scoped to specific areas of the profession reveals how expectations about librarian skills change.

The skills and knowledge librarians perceive as necessary also have been assessed through surveys and literature reviews (Table 4). A nationwide survey found interpersonal skills to be the most frequently ranked as ‘core,' followed by knowledge of professional ethics, writing, evaluating and selecting information sources, teamwork, search skills, customer service skills, cultural competence, interacting with diverse communities, reflective practice grounded in diversity and inclusion, reference interview/question negotiation, and advocacy (Saunders, 2019, p. 166). In contrast to the studies of job ads, none of the technology skills were ranked as core by more than half of respondents. In a study of 33 LIS syllabi, Bailey (2010) found the most frequent subjects were Collection Management, Budgeting/Finance, IL/Instruction, Organisation, and Personnel/Staffing/Human Resources_each mentioned in more than 20 syllabi (p. 37). Scholarly communication, management, and faculty status/tenure were listed by 20 syllabi; higher education, assessment, library facilities, and future vision were listed by more than 15 . Despite the inclusion of IL/instruction as a topic in class, those in the workplace report a greater need for education on teaching (Davis, 2007; Walter, 2008; Hall, 2013), as discussed below. 
What Librarians Do: Duties and Roles of Librarians / Value for Those Duties

Multiple researchers have attempted to summarise academic librarian roles, both generally (Table 5) and within specific areas (Table 6). Finding no American Library Association statement, Davis (2007) surveyed dictionary definitions and discovered only ambiguity. She noted the ‘constant and relevant encroachment of technology into the profession' (p. 79) and little mention of librarians’ educational or teaching roles. Weng and Ackerman (2017) observed that librarians might perceive technical services and public services as distinct, even competitive professions that might hold stereotypes about one another.

Librarians seem especially concerned with perceptions of their teaching role (Table 7), and often desire equivalent status to non-librarian faculty (Feldman \& Sciamarella, 2000). Two studies of academic librarians’ perceptions find instruction and teaching to be a frequently mentioned role for academic librarians ([LJ/Gale], 2015; Vassilakaki \& MoniarouPapaconstantinou, 2015). An LJ/Gale (2015) survey found that $84 \%$ of academic librarians had been invited to speak with students during class time (p. 27), and that $30 \%$ reported normally working with faculty on curriculum planning (p. 33). Vassilakaki and MoniarouPapaconstantinou (2015) observed librarians describing themselves as assuming 'a range of responsibilities associated with teaching and learning' (p. 41). Tennant, Cataldo, SherwillNavarro, \& Jesano (2006) discovered that liaisons found instruction to have the most impact on the success of their liaison program (p. 407), and furthermore, liaisons listed course-integrated instruction as one of their most preferred duties. Librarians see their teaching roles as flexible and evolving: in some disciplines, they allow that faculty might teach IL skills themselves ( $\mathrm{LJ} / \mathrm{Gale}$, 2015). The role of academic librarians as teachers seems to be increasing. Walter (2008) noticed an increase in library instruction sessions across multiple universities from 1994- 
2004 (although these trends weren’t normalised for institutional size over time). However, a series of studies over the past 25 years revealed that teaching still has not become part of formal education (Walter, 2008, p. 56). Librarians report that library school education does not seem to prioritise instruction or communicate how demanding the responsibility can be (Walter, 2008, p. 62) and that teaching, including opportunities to practice, should be emphasised more in library school curricula (Davis, 2007, p. 93). In a survey by Hall (2013), 87\% of supervisors said instruction was very important to the library, compared with $72 \%$ in an earlier study by Avery and Ketchner (1996) (p. 28). Supervisors overwhelmingly said instruction skills should be taught in library schools (96\%) (p. 33). Some librarians are anxious about teaching because of this lack of formal preparation, the expanding nature of their teaching role, and stereotypes. Davis (2007) found that between $25-35 \%$ of respondents do not enjoy teaching; $60 \%$ reported experiencing physical symptoms of anxiety such as sweating and upset stomach (p. 87). The librarians most likely to experience such symptoms were 'those who are somewhat bothered by librarian stereotypes or who somewhat agree that teaching faculty do not understand the librarian's teaching role' (p. 89). Perceptions of librarians as teachers is also seen as important because teaching requires extensive time and support from administrators and colleagues (Walter, 2008).

Academic librarians also are highly interested in their roles on campus, as evidenced by several investigations (Arendt \& Lotts, 2012; Ducas \& Michaud-Oystryk, 2003; Meulemans \& Carr, 2013; Ochola \& Jones, 2001; Phelps \& Campbell, 2012; Tennant et al., 2006; Yang, 2000). While many areas of the library develop relationships across campus, the literature often focuses on reference, instruction, and liaison work. Liaison librarians have reported that communication and relationship building are the top factors for success in their position (Arendt \& Lotts, 2012, p. 168), although fewer than $20 \%$ of Arendt and Lotts' liaison respondents had served on 
department committees (2012, p. 161). Librarians with extra academic credentials might feel more equivalent to other faculty (Feldman \& Sciamarella, 2000), while liaisons without academic backgrounds corresponding to their departments might see themselves less as academic partners (Ochola \& Jones, 2001). Conclusions from studies of liaison programs show librarians feel responsibility for educating faculty about services and being aware of changing faculty needs and perceptions (Yang, 2000). Based on a systematic literature review, Phelps and Campbell (2012) found reasons to believe 'that strong ties currently exist between faculty and librarians.' However, they concluded that while librarians highlight the importance of their relationships with non-librarian faculty, their true interest lies less in relationship-building and more 'in promoting the library, library services, and information literacy’ (p. 15). Moreover, librarians are 'more likely to publish critical opinions of faculty' than to explore ways to foster trust (p. 17). In response to the $L J /$ Gale (2015) survey, librarians cited the top barrier to librarians and faculty communicating and consulting with one another was lack of time (63\%), followed by ‘faculty lack of awareness of how library could support them’ (20\%) (p. 36). While lack of time also was the top-cited barrier by faculty, only $15 \%$ indicated it was actually a barrier (p. 21).

Based on a discourse analysis of journal articles, listservs, and research interviews, Hicks (2016) found that many librarians consider advocacy as a core part of their jobs, using words like 'must' and 'need' with a sense of urgency, even though they feel insecure about their advocacy abilities (p. 625). Specific tasks involved in advocacy included showing (e.g., gathering statistics, having a business plan, effective signage, making presentations, and offering instruction), and telling a story (e.g., having an elevator speech, using social media) (p. 631). Advocacy was seen as an important way to inform others about correct perceptions of librarians, especially in terms of skills, expertise, and role in their communities. While Hicks determined that librarians 
'separate themselves from the library-as-place when advocating for the profession,' when talking about services, they associate their identity with the library (p. 630). Indeed, librarians often ground their professional identity in a specific service in order to draw on 'implicitly and socially based understandings associated with these products of their work’ (p. 634).

The literature shows dynamic transformations also happening within several areas more internal to librarianship. The role of cataloguing now transcends the catalogue and encompasses other aspects of metadata and bibliographic control (Chapman, 2007; Hall-Ellis, 2006; Park, Lu, \& Marion, 2009). The prominence of electronic resources dramatically increased licensing, contract negotiation, and knowledge management functions (Goetsch, 2008).

The roles of teaching, campus engagement, advocacy, and information control and access are perhaps nowhere more interrelated than in the area of digital humanities and digital scholarship. The team-based approaches described by Cox (2016) in his review reveal a multistranded field with a "wide range of initiatives and innovation” (p. 143). While the need to communicate the library's role is clear, the blend of staff types makes it difficult, and possibly counterproductive, to identify distinct "librarian” roles in this area.

Faculty status for academic librarians has both supporters and opponents within the field (Table 8). When librarians have faculty status, administrators are perceived as listening more attentively and librarians perceive more active participation in campus governance and policymaking (Galbraith, Garrison, \& Hales, 2016). Faculty status is also perceived to enhance collaboration with non-librarian faculty (Galbraith, Garrison, \& Hales, 2016; Thompson, 2014). Librarians’ arguments against faculty status include the additional pressure, which prevents librarians from doing their work, and the belief that tenure and faculty status are unimportant (Thompson, 2014). 
What Librarians Are Like: Motivations and Affective Behaviors

As with librarians generally, academic librarians are interested in their image (Table 9). Their motivations and affective perceptions of themselves underlie messages they send when recruiting new librarians as well as outreach to patrons in need of their services (McClellan \& Beggan, 2019; White, 2012). A common top reason given for choosing librarianship is the desire to help people (Davis, 2007; Davis-Kendrick, 2009). Ard et al. (2006) surveyed 96 MLIS students and found the job functions of librarianship to be the major incentive for choosing the profession. The second-ranked motivation was another person's recommendation. Compensation was listed as a major influence by 24\% (p. 241), even though when asked what salary range they anticipated for their first job, more respondents selected a response below \$34,999 (55\%) than above this level (p. 242).

Librarians frequently report loving their jobs, with a sizable percentage intending to stick with the career (Davis, 2007; Davis-Kendrick, 2009). Research suggests they are proud of their work and think of it in positive terms. In their study of liaison librarians, Arendt and Lotts (2012) found that the majority describe themselves as successful (63\%) or very successful (13.8\%), while 63\% are satisfied or very satisfied (p. 162). After analyzing librarian job ads over the years, Goetsch (2008) highlighted the characteristics of adaptability, sound professional values, creativity, and tolerance for ambiguity (pp. 170-171). Weng and Ackerman’s (2017) survey asked 586 public and technical services librarians about their ‘core qualities’ (p. 202). The entire sample thought it was 'most important' or 'very important' that both public and technical services possess the six qualities listed in the survey, including: responsiveness to change, usercentred philosophy, collaborative nature, adaptability to technologies, forward-thinking, and motivation to start new initiatives or respond proactively (pp. 201-202). 
The confidence of librarians in their abilities can potentially be quite high. In an introduction to a special journal issue about embedded librarians, Norelli stated they often propose themselves as the most important resource in the library (2010, p. 71), Posner suggested they might develop exaggerated self-images based on success in helping a patron (2003, p. 115). Perhaps this is why Davis (2007) found that academic librarians are bothered by stereotypes, either completely (17\%) or 'to a certain degree' (38\%) (p. 85). While librarians might rate their own skills highly, a survey of 80 matched pairs of students and faculty who engaged in research consultations at a large university found reference librarians might suffer from 'provider pessimism,' where librarians think the patron is less satisfied than they actually are—in 23 cases where librarians predicted students would say the encounter was 'Somewhat Useful,' those students rated the encounter as 'Very Useful' 76\% of the time (Figure 1) (Butler \& Byrd, 2016, p. 85). The study supported similar findings between MLIS students and patrons (Hansen et al., 2009). These results point to the gap between librarian and student perceptions of the same encounter, echoing previously mentioned findings of the difference between librarian and faculty ratings of some services ( $L J /$ Gale, 2015, p. 5). Recent interviews with 24 librarians (including 15 reference librarians) at a large university explored librarians’ perceptions concerning why they might come across as unapproachable (McClellan \& Beggan, 2019). Respondents discussed how introversion or introspection relate to quietness and a "reserved" nature (p. 260). The stereotypes of librarians being service-oriented and female were mentioned by some female respondents, with some additionally commenting that their male colleagues seemed more approachable to students. The causes cited for students' perceptions included library anxiety, insufficient prior experience with librarians, and the tensions between librarians' roles as both guides to knowledge and enforcers of rules. 


\section{Literature on Faculty Perceptions of Librarians}

The library's ability to fulfill its mission is affected by non-librarian faculty perceptions of librarians because they exert significant influence on most campuses. ('Faculty' will be used to refer to 'non-librarian faculty' for the remainder of this paper.) Successful integration of library instruction into the curriculum and student services both benefit from faculty support (Arendt \& Lotts, 2012). Connections between librarians and faculty also will influence librarians' effectiveness in reaching students, partnering on campus, and being included in relevant policies (Manuel, Beck, \& Molloy, 2005). While this literature review doesn’t cover the 1980s and 1990s, it is notable that some of the more recent papers (Christiansen et al., 2004; Manuel et al., 2005) were written in reaction to the research findings of those decades. For an extensive presentation of the thinking of these decades, Kotter (1999) offers the most comprehensive review. Consensus from that time frame indicates that while faculty appreciated librarians' service roles, they did not consider them teachers or academic equals. Perceptions were that librarians did not publish on par with faculty, nor did they formally teach, but that librarians worked as professionals within the information services domain on tasks such as reference and collection development. Librarians have certainly perceived a lack of understanding of their work from faculty. In their study at six community colleges, Feldman and Sciamarella (2000) found ' $92 \%$ of the librarians felt that teaching faculty are unaware of the nature of the field of library science/information technology' (p. 493).

Another general finding is that faculty generally don't investigate academic librarians as a topic within their own research (Christiansen et al., 2004). Librarians are increasingly attending subject-specific conferences (Hankins, Melgoza, Seeger, \& Wan, 2009; Harrison, 2010), but it seems that faculty seldom attend librarian conferences. Christiansen et al. (2004) reviewed non- 
librarian-authored social science research about librarians (all of which pre-dated the present review's scope) and found that topics included gender and sexuality in the profession, use of library resources for teaching sociological research methods, 'status, prestige, and professionalism of librarians,' and the politics of library collections—but not perceptions of librarians (p. 116).

What Librarians Know: Librarian Expertise and Skills

Although few studies were found directly investigating faculty perceptions of librarians' knowledge, skills, and expertise, some inferences can be made by examining evaluation studies of liaison programs, library instruction, and librarian-faculty relationships. One study directly asking faculty about perceptions was focused on the context of library instruction (Manuel, Beck, \& Molloy, 2005). Twenty-one faculty considered to be heavy library instruction users were interviewed at a large, 4-year institution. The top motivation for these faculty to request library instruction was their perception that librarians were experts in collections, research, and overall library use. Jeffries (2000) interviewed 21 faculty at a large, 4-year institution who indicated they were interested in learning more about librarians' areas of interest, skills, and background, as well as the type of collaboration envisioned.

The evidence that faculty recognise librarians' information-seeking skills is strong (Table 10). Faculty perceive librarians as helpful with gathering information for their own research and that of their students (Feldman \& Sciammarella, 2000; Ducas \& Michaud-Oystryk, 2003; Jeffries, 2000; Weng \& Murray, 2019), with some faculty describing librarian assistance as critical (Weng \& Murray, 2019). Manuel et al. (2005) found that about half of their samples of faculty respondents valued librarian instruction for themselves rather than for students. Related to this were expressions of some value for librarians' reference abilities (Ducas \& Michaud- 
Oystryk, 2003), subject knowledge (Manuel et al., 2005), and skill in creating bibliographies, web pages, and slideshow presentations about sources, topics, and updates on new tools (Wu \& Kendall, 2006). Faculty also credit librarians with knowledge about library services and express value for librarian communications about the latest improvements and new resources (Arendt \& Lotts, 2012; Ochola \& Jones, 2001; Yang, 2000).

Faculty might lack opportunities to see domains of librarianship other than information services. Respondents to Ducas and Michaud-Oystryk’s survey (2003) reported interacting most with librarians in the area of information services (88\%), while only $38 \%$ said they had interacted with librarians in the area of collections, 33\% in the area of information technology, $20 \%$ in the area of instruction, and $7 \%$ in the area of research collaboration (p. 65). These trends might be shifting or might vary by study; in Weng \& Murray’s four-institution study, 90.5\% of faculty reported interacting with librarians, and top purposes for interaction were collection development (83\%), research assistance (64\%), and instruction requests (45\%) (p. 203). Other activities, reported by $20-40 \%$ of faculty, included digital services, faculty departmental meetings, and campus governance (p. 203). Faculty also interacted with librarians to keep up-todate in their field (15\%) and/or collaborate on research or teaching (13\%) (p. 203).

In conclusion, evidence suggests that faculty don’t think deliberately about librarians, and that their perceptions of librarians' knowledge, skills, and abilities are primarily informed by domains in which they have been engaged with a librarian.

What Librarians Do: Duties and Roles of Librarians

This literature review found that faculty have seldom been asked what they think the role of a librarian is. From conversations with a small sample of faculty at a public university and a private college, Christiansen et al. (2004) found that faculty describe librarians' roles as service- 
oriented: 'their primary duties are the organisation and facilitation of access to knowledge and other resources,' in contrast to the faculty role of 'the production and dissemination of knowledge' (p. 119). Overall, Christiansen et al. (2004) found that faculty do not have a solid understanding of librarians' work, duties, and projects. Faculty do express value for librarians’ work with collections (80\%), information technology (69\%), and research (60\%) (Ducas \& Michaud-Oystryk, 2003). In Weng \& Murray’s 2019 study, answers to qualitative comments showed, 'the vast majority' focused on academic or traditional support roles, rather than digital scholarship or emergent roles (p. 209). Since 2006, Ithaka S+R has conducted a survey of faculty at U.S. four year-institutions (in 2018, $n=10,919$ ), and asked whether they agreed that 'the librarians' role has diminished due to easier access of academic content’ (p. 56). Although from 2006 to 2012 there was a small rise in Strongly Agree responses from about 10\% to 20\%, since 2012, the 20\% has remained consistent (Ithaka S+R, 2019, p. 56). A regression analysis of the 2015 Ithaka S+R survey (n=9203) found that faculty perceptions of academic librarians’ contributions to student skill development are partially explained by faculty perceptions of frequency of student-librarian contact and how important improving student research skills was to faculty course goals (Kelly, 2019). The literature found in this section are clustered into the areas of research and information services, collection management, and teaching.

Schulte \& Sherwill-Navarro (2009) surveyed 112 nursing faculty from Indiana and Florida (the number of institutions is not known). In response to an open-ended question asking for a definition of 'what collaborating with a librarian meant to them,' respondents most commonly mentioned reference assistance (Schulte \& Sherwill-Navarro, 2009). This corresponds with Ducas \& Michaud-Orystryk’s (2003) findings where information services ranked as the most important and the most-used librarian service at one university. Forty-five percent of these 
faculty reported information services had a substantial or very substantial impact, while $49 \%$ reported 'some' impact with saving time, identifying more appropriate resources, and expanding the faculty member's subject knowledge (p. 68). At institutions with library liaisons, faculty are generally aware of this role (Arendt \& Lotts, 2012; Ochola \& Jones, 2001), but might not know what it comprises (Ochola \& Jones, 2001; Yang, 2000). In the most recent research, librarian services related to research were rated as 'important' or 'very important' to their institution by $90 \%$ of faculty at four institutions; however, fewer faculty reported research services as critical (25\%) or helpful (65\%) to them individually.

Communicating about needs and resources to faculty ranks as highly or even more highly than information services, including updating faculty on library services, consulting with faculty to support instructional needs, and conveying faculty opinions to the library administration (Ochola \& Jones, 2001; Schulte \& Sherwill-Navarro, 2009; Yang, 2000). Yet, there seems to be a wide range of individual differences: $27 \%$ of faculty respondents to the $L J / G a l e$ survey said there was 'no need' to communicate or consult with the library (2015, p. 36) and only $45 \%$ said communication needs to be better. When asked how to improve communication and encourage interaction, the most frequent suggestions were department meetings, scheduled meetings/workshops, and instructional liaisons (p. 22). Interestingly, lack of time was only cited by $15 \%$ of these faculty as a barrier to communicating with the library (p. 21).

Faculty do seem aware of librarian-faculty collaborations, even though they might not see particular value in increasing that collaboration (Christiansen et al., 2004). Responses to the $L J /$ Gale survey showed that while $98 \%$ of librarians think there needs to be better communication between the library and faculty, only $45 \%$ of faculty did (2015, p. 37). Results from the series of faculty interviews by Jeffries (2000) found that faculty perceive librarians as 
networkers and collaborators in a way that is complementary to their own roles. Faculty urged librarians to get to know them as individuals, customize their approach, and to be flexible (Jeffries, 2000). However, levels of collaborative relationships might already be perceived as good. Weng and Murray found that many more faculty reported having ‘close/trusting’ or 'collegial/courteous' relationships with their librarians than 'distant' or 'indifferent/no thoughts' (2019, p. 206). Faculty might be motivated to participate in additional collaborations if they become more aware of how other faculty are collaborating with librarians. Ducas and MichaudOystryk’s faculty identified assessment and curriculum development opportunities as highly representative examples of potential collaboration (2003). Also, faculty see some areas of collaboration as more important than librarians do, namely faculty participation in collection development and cancellation decisions, notices of new publications in the discipline, and information about copyright (Arendt \& Lotts, 2012, p. 169). Faculty attitudes toward librarians might be different based on librarians' faculty status, not necessarily in terms of quality but in terms of visibility and a feeling of solidarity (Weng \& Murray, 2019).

In the area of collections, it seems less than half of faculty might interact with librarians in this role-38\% of Ducas and Michaud-Orystryk's (2003) respondents did, and 42\% of Wu and Kendall’s (2006) business faculty did. Of Ducas and Michaud-Orystryk’s (2003) respondents who had interacted with librarians in this area, 51\% reported the interaction had a 'very substantial' to 'substantial' impact (p. 69), and said the interaction led to the development of better collections, improved communications, and awareness of collection scope and new resources. More than three-fourths of Weng and Murray’s (2019) respondents rated collection development and interlibrary loan as 'very helpful' or 'helpful' (p. 206). 
Faculty perceptions about librarians teaching might be changing over time (Table 11). Pre-2000 surveys found that faculty rated librarians’ roles in teaching library instruction as moderate to low. Faculty thought librarians lacked the disciplinary knowledge necessary to teach and felt students should learn to research on their own; some even expressed dissatisfaction with library instruction experiences (Manuel et al., 2005, pp. 140-141). Studies from 2000-2010 reported that about 20\% of faculty use library instruction (Ducas \& Michaud-Oystryk, 2003; Yang, 2000). Feldman and Sciammarella found that 36\% of their community college faculty did (2000, p. 494). Two studies since 2010 showed higher numbers; Bury’s study at a large, 4-year university (2011) reported 53\% of her 221 faculty respondents used library instruction (p. 54) and 45\% of Weng and Murray’s (2019) 505 faculty respondents reported requesting library instruction (p. 203). Saunders (2012) found high percentages of faculty agreeing information literacy instruction was a responsibility of librarians, but similarly high percentages thought information literacy was the responsibility of faculty (Figure 3). Female faculty appear to request library instruction more often than males (Bury, 2011) and business, humanities, social sciences, and health sciences more than pure and applied sciences (Ducas \& Michaud-Oystryk , 2003; Wu \& Kendall, 2006). Saunders (2012) also found a strong correlation between discipline and instruction requests (specifics were not given), but no correlation between discipline and perceptions of effectiveness, or between discipline and whether librarians or faculty should teach information literacy. A study of psychology faculty found that while they thought librarians' role was important in information psychology information literacy, for 9 of 11 information literacy indicators, they found their own role to be more important (Stanger, 2012, p. 123).

Faculty responses about whether library instruction is important have also changed over time. While two studies in the early 2000s found more faculty rating library instruction as more 
unimportant than important (Ochola \& Jones, 2001; Yang, 2000), 51\% of faculty responding to the $L J /$ Gale (2015) survey said it was 'very essential' for their campus library to provide IL instruction, with an additional 34\% saying it was 'essential’ (p. 17). IL instruction was, in fact, the most essential service these faculty thought their library provided (p. 12). Seventy-seven percent of faculty in Weng and Murray's (2019) four-institution study rated librarian teaching as 'very important' or 'important' to their institution, 20\% reported it was 'critical' to themselves individually, and 60\% reported it was 'helpful' to them individually (p. 208). Stanger's study of psychology faculty found more than 50\% reporting “it was of great or very great importance that librarians provide instructional support” on 5 of 11 information indicators (2012, p. 123). The onus still might be on librarians to promote instruction; however, as Arendt and Lotts (2012) found, librarians considered library instruction and discussing curriculum integration much more important than faculty did.

When Manuel et al. (2005) asked faculty who were considered heavy instruction users why they had a librarian provide instruction, 86\% described the librarian as an expert (p. 147). About half of these faculty also recognised that librarian-tailored course content to specific assignments gave students hands-on experience with research sources. Faculty who don't interact with librarians might find library instruction inappropriate (especially in the sciences), might not think of librarians as teachers, or might not expect students to know the information (Ducas \& Michaud-Oystryk, 2003). This ambiguity causes stress for librarians who believe faculty are unaware of what they do and hold stereotypes (Walter, 2008). Those who are anxious about teaching hold these faculty perceptions to blame (Davis, 2007).

Some studies found notable results concerning faculty perceptions of what librarians don't do, or what roles are not important for librarians. Arendt and Lotts (2012) found that both 
faculty and librarians did not indicate representation on department committees or at department functions ‘important' or 'very important' for librarians. Faculty seem to have a clear idea that librarians don’t provide information technology assistance, beyond finding online documents (Ducas \& Michaud-Oystryk, 2003, p. 71). Interestingly, some faculty (44\%) from the same survey saw roles for librarians expanding to include integrating technology into the curriculum (p. 70). Weng and Murray (2019) found that 'nearly as many respondents felt that technology hindered interactions with librarians (7\%) as felt librarians’ technological proficiency benefitted them (8\%)’ (p. 209).

What Librarians Are Like: Motivations and Affective Behaviors

While faculty might not think explicitly about their perceptions of librarians, they do recognise that librarian behaviours matter. The most common context for such discussion is found in literature concerning instruction. In Manuel et al.'s interviews (2005) with heavy instruction users, faculty reported the worst library instruction sessions were a result of disconnects between librarians and students, whether for lack of enthusiasm, use of unfamiliar language, information overload, or pace. Disconnects between faculty and librarians were reported by one-third of respondents. Examples included miscommunications in planning the session, mismatched instructional approaches, and librarians giving students different instructions than the faculty member (Manuel et al., 2005, p. 152). Manuel et al. noted the term ‘information literacy’ was only used one time by faculty (and by an education professor) during their interviews (2005, p. 157). Manuel et al. (2005) concluded that while librarians focus on meeting cognitive goals and objectives in library instruction, faculty seem to place more value on the affective domain (e.g., helping to increase student self-confidence) (p. 156). Faculty reported that instruction helped students be more comfortable with asking librarians questions later 
(Manuel, et al., 2005). Bury’s (2011) survey of faculty also found an important benefit of instruction was increased student self-confidence and motivation, with higher-quality assignments ranked as the top benefit. Faculty also reported that librarians save their students' time (Manuel, et al., 2005; Ducas \& Michaud-Oystryk, 2003).

In response to a question about their own relationships to librarians, many more of Weng and Murray’s (2009) faculty from four institutions reported having ‘close/trusting’ or 'collegial/courteous' relationships with their librarians than 'distant' or 'indifferent/no thoughts' (p. 206). When asked who should be responsible for enhancing effective partnerships between librarians and faculty, 32\% said it should be the librarians, while $17 \%$ said it should be faculty; it was unclear if 'both’ was an option (p. 209).

\section{Literature on Student Perceptions of Librarians}

Students have different interactions with academic librarians than faculty do, and simple awareness of librarians is often a foundational challenge. Perceptions of academic librarians’ status, education, knowledge and skills, duties and responsibilities, and demographic and physical characteristics might influence whether students seek assistance. Information anxiety has implications for student research behaviour and utilisation of the library (Blundell \& Lambert, 2014). While this literature review was focused on 2000-present, Hernon and Pastine’s (1977) seminal article on this subject was also included because of its significance. Some studies focused on both student and faculty perceptions or on students' perceptions of the library and library services and/or library personnel, while others explored factors that influence perceptions of librarians in general. However, fewer studies were found specifically examining student perceptions of academic librarians. This lack of direct research on college student perceptions can be seen in Black’s (2016) literature review concerning why they don’t ask for help. 
What Librarians Know: Librarian Expertise and Skills / Value for Librarians' Skills

Studies across the decades suggest students possess little knowledge about the characteristics of academic librarians’ profession (Table 12). Students are often unaware of librarians’ MLS, faculty status (Fagan, 2003; Luzius \& Noe, 2003), or career paths (Stanley, 2007). Hernon and Pastine (1977) and Fagan (2003) both found that students emphasised the value of librarians' skills in finding materials rather than in how to use materials. Only 31.6\% of Hernon and Pastine's students indicated that their interactions with librarians could be considered a learning experience ‘frequently’ or ‘always' (1977, p. 136). However, perceptions of librarian teaching skills might be expanding. Jameson, Natal, and Napp (2019) found the top reason students asked a librarian for help was ‘to learn how to use a library resource’ (48\%), which outranked 'to get help finding books' (46\%), and 'to get help finding articles' (33\%) (p. 373). And Meredith and Mussel found that 'figuring out how to narrow your search results' was the top area improved by embedded librarian tips and forum discussion, outranking 'figuring out which are the best search tools to use for your topic’ (2014, p. 97). What Librarians Do: Duties and Role of Librarians / Value for those Duties

The literature review found that student perceptions of librarians’ responsibilities also have evolved (Table 13). When Hernon and Pastine (1977) investigated this subject more than 40 years ago, the prevailing view was that librarians guided students to information rather than having a deeper role in the acquisition of IL competencies, the value of scholarly inquiry, and critical evaluation of sources. When Fagan (2003) asked what job responsibilities librarians performed regularly, student respondents listed these most often: technical activities, reference, and cataloguing/organizing tasks. With the integration of librarians in the curriculum 
and embedded in programs and departments, students now indicate that these services improve their grades and increase research proficiency (Blake et al., 2016).

The literature provides somewhat conflicting information about perceptions of reference librarianship. Hernon and Pastine (1977) found that many students believed librarians only led them to information rather than providing any knowledge themselves. Only $31.6 \%$ of students indicated that their interactions with librarians could be considered a learning experience 'frequently’ or 'always' (p. 136). And according to Jenkins' survey of students in 2001 regarding the responsibilities of reference librarians, $51 \%$ of students said it was to direct patrons to resources (p. 233). Only 32.8\% selected all options on the survey, including providing directions to providing directions to resources and spaces, answering research questions, and helping with resources (Jenkins, 2001, p. 233). But some students recognize librarians’ teaching role during reference, including helping them understand assignments, clarify topics, develop search strategies, and progress research skills (Blake et al., 2016; Magi \& Mardeusz, 2013). Face-toface consultations are perceived as valuable because of their efficiency as compared to email or chat; because in-person interactions allow them to watch the librarian's search process; and because of the interactive collaboration (Magi \& Mardeusz, 2013, p. 612). Butler \& Byrd’s 2016 study comparing librarian and student perceptions of the same research consultation found that students might perceive research consultations as more valuable than librarians expect (p. 85). Students’ perceptions of librarians now seem to include librarians in the role of teacher, which is a significant change from previous studies like Hernon and Pastine (1977) and Fagan (2003). Polger and Okamoto (2010) found that 66\% of students perceived librarians as teachers immediately before having a library instruction session (p. 5), while $80 \%$ of students perceived librarians as teachers immediately after the session. Fifty-four percent identified librarians as 
teachers when surveyed in cafeterias at the two institutions (pp. 5-6). Qualitative responses revealed some reasons why students view librarians as teachers, including, 'librarians teach students how to find information or books and they explain how to conduct research in the library’ (p. 6). Reasons students did NOT perceive librarians as teachers included, 'librarians only help, guide or lead them to books and other information' and 'students explained that librarians do not teach in a classroom, nor do they lecture' (p. 7). Polger and Okamoto speculate that the increase in library instruction might have influenced student perceptions, and that this instructional role can have a positive effect on student perceptions.

What Librarians Are Like: Motivations and Affective Behaviors

This literature review found significant interest in the question of how students perceive librarians' affect, and how that influences whether they ask for help (Table 14). Jameson et al. (2019) found students at one institution rated librarians as 'very approachable' or 'approachable' $79 \%$ of the time, with $16 \%$ choosing 'slightly approachable' (p. 375). However, the researchers noted that many of their respondents had also indicated they couldn't tell who a librarian was, so these responses might reflect impressions of library workers generally. A prevalent theme in qualitative responses was that there were no barriers to asking for help because librarians were 'warm, friendly, and knowledgeable,' and because helping is 'part of their job’ (p. 375). Only $7 \%$ of students said the reason they did not ask librarians for help was because they 'did not think a librarian could help' (p. 372). Interestingly, the top reason students didn’t ask for help was simply that they liked to figure things out on their own (p. 372). In Jenkins's (2001) study, when asked why they did not seek assistance, $64.1 \%$ of students said they never needed it and 16.9\% indicated they were uncertain how to ask for help (pp. 238-239). Fitzpatrick, Moore, and 
Lang (2008) also reported students' top reason for not asking was not having a need, but 21\% chose ‘scary’ or ‘afraid’ (p. 236).

While one study of 120 participants found that the pop culture image of librarians does not influence student perceptions (Borchard, Wimberley, Eng-Ziskin, \& Fidgeon, 2018), many studies have nevertheless provided insights into characteristics students have in mind when thinking of academic librarians, including:

- Being 'older, quieter, more ‘official-looking', and 'like they might know more' than staff at a nearby learning commons desk, who were described as 'younger, busier, less formal, less patient, and more “techy” ’ (Fitzpatrick, Moore, \& Lang, 2008, p. 236).

- Being female and wearing glasses (Borchard et al., p. 85).

- Being 'shy,' 'organized,' 'helpful,' ‘quiet,' and 'reserved,' and as someone who 'reads a lot' and 'someone who checks books in and out' (Stanley, 2007, p. 85).

- Smiling, wearing a nametag, and wearing a blue shirt (Bonnet \& McAlexander, 2013). Students who know they have interacted with librarians might come away with a more informed response about librarian’s affect. Magi and Mardeusz’s (2013) survey found students who had participated in face-to-face consultations with a librarian 'appreciated being reassured and inspired' and desired to build personal relationships with librarians (p. 613). The students also mentioned interacting with librarians ‘forced them to focus' and built their confidence (p. 613). A small number of Jameson et al.'s (2019) students commented that library classroom instruction and research consultations would make them more likely to ask for help (p. 378).

Several studies have investigated how students' demographics influence their impressions of librarian approachability and willingness to use the library or ask for help (Table 15). Long (2011) found barriers to Latino students' utilisation of the library in their 
perceptions of the library as a social and cultural place and in their uncertainty about the purpose of the library/librarians. Long suggests that efforts be made to increase diversity among library staff and create a more culturally inclusive environment (p. 510). Blundell and Lambert (2014) found freshmen 'females were more likely to believe reference librarians were unhelpful' (p. 266) and 'Caucasians were more likely to believe there is often no one available in the library to help them’ (p. 266). Bonnet and McAlexander’s (2012) sample of undergraduate students, graduate students, and faculty/staff found female librarians were perceived as more approachable and that respondents would prefer to seek help from a librarian near their age (p. 280), and for African-American respondents, of their race (p. 282). Borrelli, Su, Selden, \& Munip (2018) found that first-generation college students had limited interactions with library personnel outside of formal instruction or mandatory interaction. Such interactions were generally perceived as positive, with the only limitation identified being lack of need. Participants perceived the library as friendly and described peer-to-peer reference personnel as being more “in tune” with them while adult personnel "were perceived to have more expertise” (p. 31).

\section{Analysis of Literature on Perceptions}

\section{Common Themes}

Looking across the literature on faculty and student perceptions of librarians since 2000 in the U.S. and Canada, it is clear that certain challenges have carried over from earlier decades. The idea of librarianship as a service-oriented profession persists. Expertise that librarians have regarding subject areas is often invisible to faculty and students. The role of the academic librarian is dynamic and broad; they are deeply involved in instruction, outreach, scholarly communications, data management, etc.; however, faculty and students still have a limited view 
of the profession. To some extent, this lack of awareness is a result of only experiencing or observing a small fraction of the diverse activities librarians are involved in.

Both faculty and student perceptions are driven by where their work intersects with that of librarians. A seeming increase in library instruction might have improved the visibility of librarians as educators in the minds of faculty and students. While Yang (2000) and Ducas and Michaud-Oystryk (2003) reported about a 20\% adoption rate for instruction, the $L J /$ Gale survey reported 28\% (p. 23), and Bury (2011) and Weng \& Murray (2019) reported that 53\% and 45\% of faculty in their studies had requested instruction. And, faculty might see library instruction as more important. While in 2000 and 2001, more faculty respondents to two surveys reported instruction as less important than more important (Ochola \& Jones, 2001; Yang, 2000), 77\% of faculty in Weng \& Murray's four-institution study rated librarian teaching as 'very important' or 'important' (2019, p. 208). Given the importance of the teaching role, it is noteworthy that many librarians feel that MLIS programs do not prepare them sufficiently for teaching (Walter, 2008), although the literature also shows that librarians often have positive feelings about that aspect of their work (Davis, 2007).

A disconnect persists, however, between librarians and faculty about librarians’ roles on campus, and Christiansen et al. (2004) noted that 'each group experiences and defines the disconnection differently’ (p. 118). Librarians perceive the disconnection as problematic and interfering with their work goals but faculty 'simply do not consider it problematic' (p. 118). In contrast to the perspective of librarians, 'faculty perceive no serious problems in relations between the two groups, nor do they identify any negative consequences arising from this disconnection’ (p. 118). Faculty do not see the parts of librarian work that aren’t service-oriented and believe 'the two groups simply do different things' (p. 119). Christiansen et al. (2004) 
suggested the explanations for this disconnect are organisational-structural (e.g., 9-month vs. 12month) and perception of status difference (e.g., librarian work is service-oriented). As sociologists, they call for systematic work to investigate whether the organisational and status differences they outlined are upheld. Although disciplinary differences have not been examined systematically, beyond what might be relevant to an individual study, they also could be an important factor in perceptions around organisational and status differences between librarians and faculty.

Taking Christiansen et al. (2004) and Arendt and Lotts (2012) together, one begins to observe that librarians' perspectives are focused on their service to the university writ large, which is only partially composed of faculty. This scope of work is central to how librarians see their work, and to how 'librarians try to challenge and change ... images and stereotypes by focusing on valuable services and skills' (Hicks, 2016, p. 636). However, it does seem that faculty perceptions of librarians might be expanding (Ducas \& Michaud-Oystryk, 2003), at least in certain disciplines (Wu \& Kendall, 2006). As the review of the literature shows, many popular stereotypes of academic librarians are also changing. Research indicates that images portrayed in the media and literature do not unduly influence how students perceive librarians. And, students might be realizing librarians help them use, not just locate, information (Jameson et al., 2019; Meredith \& Mussell, 2014).

Branding and marketing practices might further affect how users understand a library's offerings and whether they know how to avail themselves of the services (O’Neill \& Guilfoyle, 2015). Students, in particular, seem confused about how to identify librarians, which directly related to whether they asked for help (Jameson et al., 2019). There was also a relationship between students who did not ask librarians for help and those who said a librarian had not 
visited their classes (Jameson et al., 2019). A library’s physical space, collections, and programs can have a notable influence on how students, especially those from underrepresented campus populations, perceive the work of academic librarians. Creating a more inclusive, representative cultural environment can facilitate student use of the library and librarians. Research analyzed for this review reveals that the perceived approachability of librarians can be swayed by affective behaviors, clothing, and race/ethnicity. Libraries and librarians should be aware of the factors that encourage or dissuade students from fully utilizing services and resources.

Student perceptions still greatly influence if and how they use library spaces and research assistance.

Future Research

A few questions emerged as areas for further exploration that were outside the scope of this study.

1. In response to the recent faculty surveys published by organisations or vendors outside of peer-reviewed journals, should academic librarians re-prioritise this topic within our scholarly discourse, perhaps specifically investigating disciplinary differences?

2. Which other disciplines are studying information seeking behavior or information anxiety that might not be explicitly examining librarians?

3. The literature focused heavily on the teaching role of public services librarians, specifically those designated as liaisons. How can we better study the various teaching roles and other roles of librarians outside of public services?

4. What interventions can mitigate provider pessimism after interactions with users? 
This literature review illuminated a complex web of perceptions among librarians, faculty, and students about academic librarians. To further investigate the perceptions of each group, a survey was conducted at James Madison University with each population. Results from each survey will be presented in subsequent papers, engaging with the respective population from this literature review. Analysis across the groups, incorporating the findings of this literature review, will be presented in the final paper. 


\section{Disclosure statement}

No potential conflicts of interest reported by the authors. 


\section{References}

Alabi, J. (2015). Racial microaggressions in academic libraries: Results of a survey of minority and non-minority librarians. The Journal of Academic Librarianship, 41(1), 47-53. doi:

\section{$\underline{10.1016 / \text { j.acalib.2014.10.008 }}$}

Ard, A., Clemmons, S., Morgan, N., Sessions, P., Spencer, B., Tidwell, T., \& West, P. J. (2006). Why library and information science? The results of a career survey of MLIS students along with implications for reference librarians and recruitment. Reference \& User Services Quarterly, 45(3), 236-248. Retrieved from

\section{https://www.jstor.org/stable/20864520}

Arendt, J., \& Lotts, M. (2012). What liaisons say about themselves and what faculty say about their liaisons, a U.S. survey. Portal: Libraries and the Academy, 12(2), 155-177. doi: $\underline{10.1353 / \text { pla.2012.0015 }}$

Avery, C., \& Ketchner, K. (1996). Do instruction skills impress employers? College \& Research Libraries, 57(3), 249-258. doi: 10.5860/crl_57_03_249

Bailey, E. C. (2010). Educating future academic librarians: An analysis of courses in academic librarianship. Journal of Education for Library and Information Science, 51(1), 30-42. Retrieved from https://www.jstor.org/stable/20720479

Black, S. (2016). Psychosocial reasons why patrons avoid seeking help from librarians: A literature review. The Reference Librarian, 57(1), 35-56. doi:

\section{$\underline{10.1080 / 02763877.2015 .1096227}$}

Blake, L., Ballance, D., Davies, K., Gaines, J. K., Mears, K., Shipman, P. Burchfield, V. (2016). Patron perception and utilization of an embedded librarian program. Journal of the Medical Library Association, 104(3), 226-230. doi: 10.3163/1536-5050.104.3.008 
Blundell, S., \& Lambert, F. (2014). Information anxiety from the undergraduate student perspective: A pilot study of second-semester freshmen. Journal of Education for Library and Information Science, 55(4), 261-273.

Bolger, D. F., \& Smith, E. T. (2006). Faculty status and rank at liberal arts colleges: An investigation into the correlation among faculty status, professional rights and responsibilities, and overall institutional quality. College \& Research Libraries, 67(3), 217-229. https://crl.acrl.org/index.php/crl/article/viewFile/15794/17240

Bonnet, J. L., \& McAlexander, B. (2012). Structural diversity in academic libraries: A study of librarian approachability. The Journal of Academic Librarianship, 38, 277-286. doi: 10.1016/j.acalib.2012.06.002

Bonnet, J. L., \& McAlexander, B. (2013). First impressions and the reference encounter: The influence of affect and clothing on librarian approachability. The Journal of Academic Librarianship, 39(4), 335-346. doi: 10.1016/j.acalib.2012.11.025

Borchard, L., Wimberley, L., Eng-Ziskin, S., \& Fidgeon, A. (2018). Should we shush about the stereotype? Examining student-generated images of librarians. Practical Academic Librarianship: The International Journal of the SLA, 8(1), 28-53. Retrieved from https://journals.tdl.org/pal/index.php/pal/article/view/7036

Borrelli, S., Su, C., Selden, S., \& Munip, L. (2019). Investigating first-generation students’ perceptions of library personnel: A case study from the Penn State University Libraries. Performance Measurement \& Metrics, 20(1), 27-36. doi: 10.1108/PMM-07-2018-0018 Bury, S. (2011). Faculty attitudes, perceptions and experiences of information literacy: A study across multiple disciplines at York University, Canada. Journal of Information Literacy, 5(1), 45-64. https://doi.org/10.11645/5.1.1513 
Butler, K., \& Byrd, J. (2016). Research consultation assessment: Perceptions of students and librarians. Journal of Academic Librarianship, 42(1), 83-86. doi:

\subsection{6/j.acalib.2015.10.011}

Carmichael, J. V. (1992). The male librarian and the feminine image: A survey of stereotype, status, and gender perceptions. Library and Information Science Research, 14, 411-446.

Chapman, J. W. (2007). The roles of the metadata librarian in a research library. Library Resources \& Technical Services, 51(4), 279-285. doi: 10.5860/lirts.51n4.279

Choi, Y., \& Rasmussen, E. (2009). What qualifications and skills are important for digital librarian positions in academic libraries? A job advertisement analysis. The Journal of Academic Librarianship, 35(5), 457-467. doi: 10.1016/j.acalib.2009.06.003

Christiansen, L., Stombler, M., \& Thaxton, L. (2004). A report on librarian-faculty relations from a sociological perspective. The Journal of Academic Librarianship, 30(2), 116-121. doi: $\underline{10.1016 / j . a c a l i b .2004 .01 .003}$

Cox, J. (2016). Communicating new library roles to enable digital scholarship: A review article. New Review of Academic Librarianship, 22(2-3), 132-147. doi: $\underline{10.1080 / 13614533.2016 .1181665}$

Cox, A. M., \& Corrall, S. (2013). Evolving academic library specialties. Journal of the American Society for Information Science and Technology, 64(8), 1526-1542. doi: $\underline{10.1002 / a s i .22847}$

David, I., \& Scherdin, M. J. (1994). Librarians in transition: Profiles on the Strong Interest Inventory. In M. J. Scherdin (Ed.), Discovering librarians: Profiles of a profession (pp. 102-121). Chicago, IL: Association of College and Research Libraries. 
Davis, K. D. (2007). The academic librarian as instructor: A study of teacher anxiety. College \& Undergraduate Libraries, 14(2), 77-101. do10.1300/J106v14n02 06

Davis-Kendrick, K. D. (2009). The African-American male librarian: Motivational factors in choosing a career in library and information science. Behavioral \& Social Sciences Librarian, 28(1-2), 23-52. doi: 10.1080/01639260902862066

Delacroix, S. A. (1994). SIGI PLUS: A case study in changing images. In Scherdin, M. J. (Ed.), Discovering librarians: Profiles of a profession (pp. 32-46). Chicago, IL: ACRL.

Detmering, R., \& Sproles, C. (2012). Forget the desk job: Current roles and responsibilities in entry-level reference job advertisements. Faculty Scholarship, 73(6): 543-555. doi: $10.5860 / \mathrm{crl}-304$

Ducas, A. M., \& Michaud-Oystryk, N. (2003). Toward a new enterprise: Capitalizing on the faculty-librarian partnership. College and Research Libraries, 64(1), 55-74. doi: $\underline{10.5860 / \mathrm{crl} .64 .1 .55}$

Fagan, J. (2003). Students’ perceptions of academic librarians. The Reference Librarian, 37(78), 131-148. doi: 10.1300/J120v37n78_09

Feldman, D., \& Sciammarella, S. (2000). Both sides of the looking glass: Librarian and teaching faculty perceptions of librarianship at six community colleges. College \& Research Libraries, 61(6), 491-497. doi: 10.5860/crl.61.6.491

Fitzpatrick, E. B., Moore, A. C., \& Lang, B. W. (2008). Reference librarians at the reference desk in a learning commons: A mixed methods evaluation. The Journal of Academic Librarianship, 34(3), 231-238. doi: 10.1016/j.acalib.2008.03.006

Frederiksen, L. (2005). Access services librarians: A content analysis of job advertisements, 1977-2004. Journal of Access Services, 3(2), 15-27. doi: 10.1300/J204v03n02_02 
Gaines, A. (2014). That's women's work: Pink-collar professions, gender, and the librarian stereotype. In N. Pagowsky \& M. Rigby (Eds.), The librarian stereotype: Deconstructing perceptions and presentations of information work (pp. 85-109). Chicago: Association of College and Research Libraries.

Galbraith, Q., Garrison, M., \& Hales, W. (2016). Perceptions of faculty status among academic librarians. College \& Research Libraries, 77(5), 582-594. doi: 10.5860/crl.77.5.582

Gerolimos, M., Malliari, A., \& Iakovidis, P. (2015). Skills in the market: An analysis of skills and qualifications for American librarians. Library Review, 64(1/2), 21-35. doi: 10.1108/LR-06-2014-0063

Goetsch, L. A. (2008). Reinventing our work: New and emerging roles for academic librarians. Journal of Library Administration, 48(2), 157-172. doi: 10.1080/01930820802231351

Gonzales, R. (2001). Opinions and experiences of university faculty regarding library research instruction: Results of a web-based survey at the University of Southern Colorado. Research Strategies, 18(3), 191-201. doi: 10.1016/S0734-3310(02)00090-3

Grimes, M. F., \& Grimes, P. W. (2008). The academic librarian labor market and the role of the master of library science degree: 1975 through 2005. The Journal of Academic Librarianship, 34(4), 332-339. doi: 10.1016/j.acalib.2008.05.023

Hall, R. A. (2013). Beyond the job ad: Employers and library instruction. College \& Research Libraries, 74(1), 24-38. doi: $\underline{\text { 10.5860/crl-236 }}$

Hall-Ellis, S. D. (2006). Cataloging electronic resources and metadata: employers' expectations as reflected in American Libraries and AutoCAT, 2000-2005. Journal of Education for Library and Information Science, 47(1), 38-51. doi: 10.2307/40324336 
Han, M-J., \& Hswe, P. (2010, July). The evolving role of the metadata librarian: Competencies found in job descriptions. Library Resources \& Technical Services, 54(3), 129-141. doi:

\section{$\underline{10.5860 / 1 r t s .54 n 3.129}$}

Hankins, R., Melgoza, P., Seeger, C., \& Wan, G. (2009). Meeting our users where they conference: A Texas A\&M model to support librarian attendance at subject-specific conferences. Public Services Quarterly, 5(2), 98-113. doi:10.1080/15228950902837541

Hansen, D., Johnson, M., Norton, E., McDonough, A. (2009). Virtual provider pessimism: Analysing instant messaging reference encounters with the pair perception comparison method. Information Research, 14 (4). Retrieved from http://www.informationr.net/ir/144/paper416.html

Harrison, R. (2010). Unique benefits of conference attendance as a method of professional development for LIS professionals. The Serials Librarian, 59(3-4), 263-270. doi: $\underline{10.1080 / 0361526 X .2010 .489353}$

Hayes, J. B., Parks, C., McNeilly, S., \& Johnson, P. (2018). Boomers to Millennials: Generational stereotypes at work in academic librarianship. The Journal of Academic Librarianship, 44(6), 845-853. doi: 10.1016/j.acalib.2018.09.011

Hernon, P., \& Pastine, M. (1977). Student perceptions of academic librarians. College and Research Libraries, 38, 129-139. doi: 10.5860/crl_38_02_129

Hicks, D. (2016). Advocating for librarianship: The discourses of advocacy and service in the professional identities of librarians. Library Trends, 64(3), 615-640. doi: $\underline{10.1353 / l i b .2016 .0007}$

Holley, E. G. (1976). Academic libraries in 1876. College \& Research Libraries, 37(1), 15-47. doi: $\underline{10.5860 / c r l \_37 \_01 \_15}$ 
Ithaka S+R. (2019). Ithaka S+R US faculty survey 2018 [Report]. New York: Ithaka S+R. doi:

\section{$\underline{10.18665 / \mathrm{sr} .311199}$}

Jackson, M. G. (1999). Image and status: Academic librarians and the new professionalism. Advances in Librarianship, 23, 93-115.

Jameson, J., Natal, G., \& Napp, J. (2019). Evolving and enduring patterns surrounding student usage and perceptions of academic library reference services. College \& Research Libraries, 80(3), 366. Retrieved from https://crl.acrl.org/index.php/crl/article/view/17116

Jeffries, Shellie. (2000). The librarian as networker: Setting the standard for higher education. In D. Raspa and D. Ward (Eds.), The collaborative imperative: Librarians and faculty working together in the information universe (pp. 114-129). Chicago: American Library Association.

Jenkins, S. (2001). Undergraduate perceptions of the reference collection and the reference librarian in an academic library. The Reference Librarian, 35(73), 229-241. doi: 10.1300/J120v35n73_01

Jennings, E. (2016). The librarian stereotype: How librarians are damaging their image and profession. College \& Undergraduate Libraries, 23(1), 93-100. doi: $\underline{10.1080 / 10691316.2016 .1134241}$

Kelly, S. L. (2019). Faculty perceptions of librarian value: The moderating relationship between librarian contact, course goals, and students’ research skills. The Journal of Academic Librarianship, 45(3), 228-233. doi: 10.1016/j.acalib.2019.03.003

Kim, J., Warga, E., \& Moen, W. E. (2013). Competencies required for digital curation: An analysis of job advertisements. International Journal of Digital Curation, 8(1), 66-83. doi: $10.2218 /$ ijdc.v8i1.242 
Kneale, R. (2009). You don't look like a librarian: Shattering stereotypes and creating positive new images in the internet age. Medford, New Jersey: Information Today.

Kotter, W. R. (1999). Bridging the great divide: Improving relations between librarians and classroom faculty. The Journal of Academic Librarianship, 25(4), 294-303. doi: $\underline{10.1016 / \text { S0099-1333(99)80030-5 }}$

Library Journal \& Gale Cengage. (2015). Bridging the librarian-faculty gap in the academic library [Report]. Retrieved from https://s3.amazonaws.com/WebVault/surveys/LJ_AcademicLibrarySurvey2015_results.p $\underline{\mathrm{df}}$

Liestman, D. (2003). Looking back to the future: Turn of the last century librarians look ahead to the twentieth century. The Reference Librarian, 37(78), 25-46. doi:

\section{$\underline{10.1300 / J 120 v 37 n 78 \_03}$}

Long, D. (2011). Latino students’ perceptions of the academic library. Journal of Academic Librarianship, 37(6), 504-511. doi: 10.1016/j.acalib.2011.07.007

Luzius, J., \& Noe, N. (2003). Do they know who we are? Student perceptions of university librarians. Alabama Librarian, 53(2), 13-16.

Magi, T. J., \& Mardeusz, P. E. (2013). Why some students continue to value individual, face-toface research consultations in a technology-rich world. College \& Research Libraries 74, (6), 605-618. doi: $\underline{10.5860 / \mathrm{crl} 12-363}$

Manuel, K., Beck, S. E., \& Molloy, M. (2005). An ethnographic study of attitudes influencing faculty collaboration in library instruction. The Reference Librarian, 43(89-90), 139161. doi: 10.1300/J120v43n89_10 
Martin, P. N., \& Park, L. (2011). Reference desk consultation assignment. Reference \& User Services Quarterly, 49(4), 333-340. doi: 10.5860/rusq.49n4.333

Mathews, J. M., \& Pardue, H. (2009). The presence of IT skill sets in librarian position announcements. College \& Research Libraries, 70(3), 250-257. doi: $\underline{\text { 10.5860/0700250 }}$

McClellan, S., \& Beggan, J. K. (2019). Addressing the dilemma of the ironic librarian: Selfreported strategies librarians use to enhance approachability. Library Quarterly, 89(3), 254-273. doi: 10.1086/703471Meredith, W., \& Mussell, J. (2014). Amazed, appreciative, or ambivalent? Student and faculty perceptions of librarians embedded in online courses. Internet Reference Services Quarterly, 19(2), 89-112. doi: $\underline{10.1080 / 10875301.2014 .917756}$

Meulemans, Y. N., \& Carr, A. (2013). Not at your service: Building genuine faculty-librarian partnerships. Reference Services Review, 41(1), 80-90. doi:

\section{$\underline{10.1108 / 00907321311300893}$}

Meyer, R. W. (1999). A measure of the impact of tenure. College \& Research Libraries, 60(2), 110-119.

Norelli, B. P. (2010). Embedded librarianship, inside out. Public Services Quarterly, 6(2-3), 6974. doi: $\underline{10.1080 / 15228959.2010 .502879}$

Ochola, J. N., \& Jones, P. J. (2001). Assessment of the liaison program at Baylor University. Collection Management, 26(4), 29-41. doi: 10.1300/J105v26n04_03

O’Neill, K. L., \& Guilfoyle, B. A. (2015). Sign, sign, everywhere a sign: What does 'reference' mean to academic library users? The Journal of Academic Librarianship, 41(4), 386-393. doi: $\underline{\text { 10.1016/j.acalib.2015.05.007 }}$ 
Pagowsky, N., \& DeFrain, E. (2014, June). Ice ice baby: Are librarian stereotypes freezing us out of instruction? In the Library with the Lead Pipe. Retrieved from https://doaj.org

Pagowsky, N., \& Rigby, M. (Eds.). (2014). The librarian stereotype: Deconstructing perceptions and presentations of information work. Chicago, IL: Association of College and Research Libraries.

Park, J., \& Lu, C. (2009). Metadata professionals: Roles and competencies as reflected in job announcements, 2003-2006. Cataloging \& Classification Quarterly, 47(2), 145-160. doi: $\underline{10.1080 / 01639370802575575}$

Park, J., Lu, C., \& Marion, L. (2009). Cataloging professionals in the digital environment: A content analysis of job descriptions. Journal of the American Society for Information Science and Technology, 60(4), 844-857. doi: 10.1002/asi.21007

Phelps, S. F., \& Campbell, N. (2012). Commitment and trust in librarian-faculty relationships: A systematic review of the literature. The Journal of Academic Librarianship, 38(1), 13-19. doi: $\underline{10.1016 / j . a c a l i b .2011 .11 .003 ~}$

Polger, M. A., \& Okamoto, K. (2010). 'Can’t anyone be a teacher anyway?’: Student perceptions of academic librarians as teachers. Library Philosophy \& Practice, 1-16. Retrieved from https://digitalcommons.unl.edu/libphilprac/328/

Posner, B. (2003). Know-it-all librarians. The Reference Librarian, 37(78), 111-129. doi: $\underline{10.1300 / J 120 v 37 n 78 \_08}$

Radford, G. P., \& Radford, M. L. (2001). Libraries, librarians, and the discourse of fear. Library Quarterly, 71(3), 299. doi: $\underline{10.1086 / 603283}$ 
Rebmann, K. R., Molitor, S., \& Rainey, B. (2012). Distance learning skills and responsibilities: A content analysis of job announcements 1996-2010. Journal of Library \& Information Services in Distance Learning, 6(2), 100-116. doi: 10.1080/1533290X.2012.693904

Salinero, D., \& Grogg, J. (2005). May the bun be with you: An annotated bibliography of librarians and their image. The Southeastern Librarian, 53(3). Retrieved from https://digitalcommons.kennesaw.edu/seln/vol53/iss3/8

Saunders, L. (2019). Core and more: Examining foundational and specialized content in library and information science. Journal of Education for Library and Information Science; North York, 60(1), 3-34. doi: 10.3138/jelis.60.1.2018-0034

Saunders, L. (2012). Faculty perspectives on information literacy as a student learning outcome. The Journal of Academic Librarianship, 38(4), 226-236. doi: 10.1016/j.acalib.2012.06.001

Scherdin, M. J. (1994). Discovering librarians: Profiles of a profession. Chicago: Association of College and Research Libraries: American Library Association.

Schulte, S. J., \& Sherwill-Navarro, P. J. (2009). Nursing educators’ perceptions of collaboration with librarians. Journal of the Medical Library Association , 97(1), 57-60. doi: $\underline{10.3163 / 1536-5050.97 .1 .013 ~}$

Shahbazi, R., Fahimnia, F., \& Khoshemehr, A. H. (2016). Analyzing the market of newly emerging IT-based jobs in library and information science and identifying IT librarian competencies. International Journal of Information Science and Management, 14(2), 59-

81. Retrieved from https://ijism.ricest.ac.ir/index.php/ijism/article/view/792

Stanger, K. (2012). Whose hands ply the strands? Survey of Eastern Michigan University psychology faculty regarding faculty and librarian roles in nurturing psychology 
information literacy. Behavioral \& Social Sciences Librarian, 31(2), 112-127. doi: $\underline{10.1080 / 01639269.2012 .713845}$

Stanley, M. J. (2007). Case study: Where is the diversity? Focus groups on how students view the face of librarianship. Library Leadership \& Management, 21(2), 83-89. Retrieved from http://hdl.handle.net/1805/1440

Tennant, M. R., Cataldo, T., Sherwill-Navarro, P., \& Jesano, R. (2006). Evaluation of a liaison librarian program: Client and liaison perspectives. Journal of the Medical Library Association, 94(4), 402-409. Retrieved from https://www.ncbi.nlm.nih.gov/pmc/articles/PMC1629425/

Thompson, C. (2014). Disciplinary differences between faculty in library use and perceptions (Thesis). Retrieved from https://mospace.umsystem.edu/xmlui/handle/10355/43258

Thornton, J. K. (2000). Job satisfaction of librarians of African descent employed in ARL academic libraries. College \& Research Libraries, 61(3), 217-232. doi:

\section{$\underline{10.5860 / \mathrm{crl} .61 .3 .217}$}

Vassilakaki, E., \& Moniarou-Papaconstantinou, V. (2014). Identifying the prevailing images in library and information science profession: is the landscape changing? New Library World, 115(7), 355-375. doi: 10.1108/NLW-03-2014-0029

Vassilakaki, E., \& Moniarou-Papaconstantinou, V. (2015). A systematic literature review informing library and information professionals’ emerging roles. New Library World, 116(1/2), 37-66. doi: 10.1108/NLW-05-2014-0060

Walter, S. (2008). Librarians as teachers: A qualitative inquiry into professional identity. College \& Research Libraries, 69(1), 51-71. doi: 10.5860/crl.69.1.51 
Wang, H., Tang, Y., \& Knight, C. (2010). Contemporary development of academic reference librarianship in the United States: A 44-year content analysis. The Journal of Academic Librarianship, 36(6), 489-494. doi: 10.1016/j.acalib.2010.08.004

Weng, C., \& Ackerman, E. (2017). Towards sustainable partnership: examining cross perceptions of public and technical services academic librarians. Library Resources \& Technical Services, 61(4), 198-211. doi: $\underline{10.5860 / 1 r t s .61 n 4.198}$

Weng, C., \& Murray, D. (2019). Faculty perceptions of librarians and library services: Exploring the impact of librarian faculty status and beyond. Association of College and Research Libraries Conference Proceedings, 200-210. Cleveland, OH.

White, A. (2012). Not your ordinary librarian: Debunking the popular perceptions of librarians. Oxford: Chandos.

Wu, L., \& Li, P. (2008). What do they want? A content analysis of Medical Library Association reference job announcements, 2000-2005. Journal of the Medical Library Association,

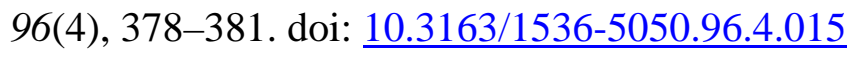

Wu, Y. D., \& Kendall, S. L. (2006). Teaching faculty’s perspectives on business information literacy. Reference Services Review, 34(1), 86-96. doi: $\underline{10.1108 / 00907320610648789}$

Xia, J., \& Wang, M. (2014). Competencies and responsibilities of social science data librarians: An analysis of job descriptions. College \& Research Libraries, 75(3), 362-388. doi:

\section{$\underline{10.5860 / \mathrm{crl} 13-435}$}

Yang, Z. Y. (Lan). (2000). University faculty’s perception of a library liaison program: A case study. The Journal of Academic Librarianship, 26(2), 124-128. doi: 10.1016/S0099$\underline{1333(99) 00149-4}$ 
Zhang, L. (2008). Foreign language skills and academic library job announcements: A survey and trends analysis, 1966-2006. The Journal of Academic Librarianship, 34(4), 322-331. doi: $\underline{10.1016 / j . a c a l i b .2008 .05 .005}$

\section{Tables}

Table 1. Comprehensive literature reviews about perceptions of librarians

\begin{tabular}{|l|l|}
\hline Citation & Description \\
\hline Jackson (1999) & Summary of historical perceptions of academic librarians, 1960s-1990s \\
\hline Salinero \& Grogg (2005) & Longitudinal annotated bibliography, 1986-2004 \\
\hline Pagowsky \& Rigby (2014) & Scholarly monograph with diverse images of information work \\
\hline Vassilakaki \& Moniarou- & Systematic literature review of librarians’ image, English-language \\
Papaconstantinou (2014) & publications, 2000-2013 (mainly academic) \\
\hline Vassilakaki \& Moniarou- & $\begin{array}{l}\text { Systematic literature review of librarians' roles, English-language } \\
\text { Papaconstantinou (2015) }\end{array}$ \\
publications, 2000-2014 (mainly academic)
\end{tabular}

Table 2. Search strategies for the literature reviews

\begin{tabular}{|c|c|}
\hline Section & Strategy \\
\hline $\begin{array}{l}\text { Librarians' perceptions of } \\
\text { librarians }\end{array}$ & $\begin{array}{l}\text { - Library, Information Science and Technology Abstracts: librarian* N5 (self- } \\
\text { image* OR self-perception* OR stereotype*) } \\
\text { - Google Scholar was also searched for '+librarian job descriptions analysis.' }\end{array}$ \\
\hline $\begin{array}{l}\text { Faculty perceptions of } \\
\text { librarians }\end{array}$ & $\begin{array}{l}\text { - Library, Information Science and Technology Abstracts: 'faculty n5 perception } \\
\text { n5 librarian*' } \\
\text { o Note: LISTA not included in initial round; full date range searched in } \\
\text { LISTA in September } 2019 . \\
\text { - Google Scholar was used with combinations of the keywords 'faculty,' } \\
\text { 'perceptions,' 'academic librarians,' 'collaboration,' and 'relationships.' }\end{array}$ \\
\hline $\begin{array}{l}\text { Student perceptions of } \\
\text { librarians }\end{array}$ & $\begin{array}{l}\text { - Library, Information Science and Technology Abstracts: (perceptions OR } \\
\text { stereotypes OR images OR attitudes) AND SU academic librarians AND SU } \\
\text { (undergraduates OR student). } \\
\text { - Google Scholar not used except for citation searching (see below) due to } \\
\text { bibliographic abundance. }\end{array}$ \\
\hline \multicolumn{2}{|c|}{$\begin{array}{l}\text { For all of the above, articles meeting the overall criteria (2000-2018, U.S. and Canada) were retained, and their } \\
\text { bibliographies were examined for additional citations. Google Scholar was then used to search for citations } \\
\text { referring to these articles. Initial searches were performed in early 2019, with a second round in LISTA in } \\
\text { September } 2019 \text { for } 2019 \text { articles. }\end{array}$} \\
\hline
\end{tabular}


Table 3: Content analyses of job advertisements

\begin{tabular}{|c|c|}
\hline \multicolumn{2}{|l|}{ All academic librarians } \\
\hline Goetsch (2008) & $\begin{array}{l}\text { Comparison of academic librarian job ads from 1995, 2000, and } 2005 \text { regarding } \\
\text { library skills, especially those not learned through library and information science } \\
\text { (LIS) education and training }\end{array}$ \\
\hline Grimes \& Grimes (2008) & $\begin{array}{l}\text { Content analysis of more than 4,000 academic librarian job ads from } 1975 \text { to } 2005 \\
\text { concerning the MLS degree }\end{array}$ \\
\hline $\begin{array}{l}\text { Gerolimos, Malliari, \& } \\
\text { Iakovidis (2015) }\end{array}$ & $\begin{array}{l}\text { Content analysis of } 133 \text { academic librarian job advertisements concerning the MLIS } \\
\text { degree }\end{array}$ \\
\hline \multicolumn{2}{|c|}{ Specific professional areas (in order by professional area) } \\
\hline Frederiksen (2005) & Access services positions, $1977-2004$ \\
\hline Hall-Ellis (2006) & Cataloging and metadata, 2000-2005 \\
\hline $\begin{array}{l}\text { Kim, Warga, \& Moen } \\
\text { (2013) }\end{array}$ & Digital curation professionals, Oct 2011-April 2012 \\
\hline $\begin{array}{l}\text { Choi \& Rasmussen } \\
\text { (2009) }\end{array}$ & Digital librarian positions in academic libraries, 1999-2007 \\
\hline $\begin{array}{l}\text { Rebmann, Molitor, \& } \\
\text { Rainey (2012) }\end{array}$ & Distance learning librarians, 1996-2010 \\
\hline Zhang (2008) & Foreign language skills in academic libraries, 1966-2006 \\
\hline $\begin{array}{l}\text { Mathews \& Pardue } \\
\text { (2009) }\end{array}$ & Information technology librarians, October 1, 2007-March 22, 2008 \\
\hline $\begin{array}{l}\text { Shahbazi, Fahimnia, \& } \\
\text { Khoshemehr (2016) }\end{array}$ & Information technology librarians, 2013 \\
\hline Chapman (2007) & Metadata librarians, 2001-2006 \\
\hline Han \& Hswe (2010) & Metadata librarians, 2000-2008 \\
\hline Park \& Lu (2009) & Metadata professionals, 2003-2006 \\
\hline Wu \& Li (2008) & Reference librarians, 2000-2005 \\
\hline $\begin{array}{l}\text { Detmering \& Sproles } \\
\text { (2012) }\end{array}$ & Reference librarians (entry-level academic) positions, January-December 2010 \\
\hline $\begin{array}{l}\text { Wang, Tang, \& Knight } \\
\text { (2010) }\end{array}$ & Reference librarians (academic), 1966-2009 \\
\hline Xia \& Wang (2014) & Social sciences data librarians, 2005-2012 \\
\hline
\end{tabular}


Table 4. Academic librarian perceptions of knowledge and skills of academic librarians (beyond job advertisements)

\begin{tabular}{|c|c|c|}
\hline Citation & Study method & Core / primary duties / roles of academic librarians \\
\hline $\begin{array}{l}\text { Davis } \\
\text { (2007) }\end{array}$ & $\begin{array}{l}\text { ILI-I listserv survey (n=382) } \\
\text { about library anxiety }\end{array}$ & $\begin{array}{l}\text { - Participants stated that teaching, including opportunities to } \\
\text { practice, should be emphasised more in library school curricula } \\
\text { (p. 93). }\end{array}$ \\
\hline $\begin{array}{l}\text { Walter } \\
(2008)\end{array}$ & $\begin{array}{l}\text { Six librarians interviewed at a } \\
\text { 'doctoral/research—extensive } \\
\text { institution' }\end{array}$ & $\begin{array}{l}\text { Concurred that library school education does not seem to } \\
\text { prioritise instruction or communicate how demanding the } \\
\text { responsibility can be (p. } 62 \text { ). }\end{array}$ \\
\hline $\begin{array}{l}\text { Bailey } \\
(2010)\end{array}$ & $\begin{array}{l}\text { Literature review and analysis } \\
\text { of } 33 \text { LIS syllabi for courses } \\
\text { in academic librarianship }\end{array}$ & $\begin{array}{l}\text { - More than } 20 \text { syllabi mentioned collection management, } \\
\text { budgeting/finance, IL/instruction, organisation, and } \\
\text { personnel/staffing/human resources. } \\
\text { - } 20 \text { syllabi mentioned scholarly communication, management, } \\
\text { and faculty status/tenure } \\
\text { - } 15-19 \text { syllabi mentioned higher education, assessment, library } \\
\text { facilities, and future vision (p. } 37 \text { ). }\end{array}$ \\
\hline $\begin{array}{l}\text { Saunders } \\
\text { (2019) }\end{array}$ & $\begin{array}{l}\text { Nationwide survey of over } \\
2,000 \text { information } \\
\text { professionals and LIS school } \\
\text { faculty asking them to rate } 53 \\
\text { skills }\end{array}$ & $\begin{array}{l}\text { - } 11 \text { skills identified as 'core' by at least } 50 \% \text { of the 2,412 } \\
\text { respondents: Interpersonal skills, knowledge of professional } \\
\text { ethics, writing, evaluating and selecting information sources, } \\
\text { teamwork, search skills, customer service skills, cultural } \\
\text { competence, interacting with diverse communities, reflective } \\
\text { practice grounded in diversity and inclusion, reference } \\
\text { interview/question negotiation, and advocacy (p. 166). } \\
\text { - Many more skills were rated very important or important. } \\
\text { - None of the technology skills was ranked as core by more than } \\
\text { half of respondents. The top two technology skills ranked as } \\
\text { core were knowledge of online security issues and } \\
\text { troubleshooting software. }\end{array}$ \\
\hline
\end{tabular}


Table 5. Academic librarian perceptions of duties and roles of librarians, and/or related findings across all types of librarians

\begin{tabular}{|c|c|c|}
\hline Citation & Study method & Duties, roles, and related findings \\
\hline \multicolumn{3}{|c|}{ All types of academic librarians } \\
\hline $\begin{array}{l}\text { Feldman \& } \\
\text { Sciamarella (2000) }\end{array}$ & $\begin{array}{l}\text { Survey of } 157 \text { faculty and } 52 \\
\text { librarians at six community } \\
\text { colleges }\end{array}$ & $\begin{array}{l}\text { - } 67 \% \text { of librarians held a second master's degree, } \\
\text { and } 44 \% \text { had conducted research in their field } \\
\text { and/or published in the last five years } \\
\text { - } 48 \% \text { of librarians had served as a liaison to an } \\
\text { academic department, while } 21 \% \text { of teaching } \\
\text { faculty had served as a liaison to the library } \\
\text { - } 52 \% \text { of librarians have served on academic senate } \\
\text { or a college committee (p. } 492 \text { ). }\end{array}$ \\
\hline Cox \& Corrall (2013) & $\begin{array}{l}\text { Literature review using } \\
\text { Abbott’s (1988) system of } \\
\text { professions }\end{array}$ & $\begin{array}{l}\text { Specialties included systems librarians, e-resource } \\
\text { librarians, digital librarians, repository managers, } \\
\text { clinical librarians, digital asset managers, web } \\
\text { managers, and teaching librarians. }\end{array}$ \\
\hline$L J /$ Gale (2015) & $\begin{array}{l}\text { Survey of } 547 \text { faculty from } \\
\text { 'Gale's faculty list' and } 499 \\
\text { librarians from 'a Library } \\
\text { Journal list' }\end{array}$ & $\begin{array}{l}\text { - Librarians identified four 'primary, essential' } \\
\text { services: 'instruction of students in information } \\
\text { literacy,' 'development of collections in direct } \\
\text { support of course curricula,' 'aiding students one- } \\
\text { on-one in conducting research,' and 'development } \\
\text { of discipline-wide collections' (p. 4). }\end{array}$ \\
\hline $\begin{array}{l}\text { Vassilakaki \& } \\
\text { Moniarou- } \\
\text { Papaconstantinou } \\
(2015)\end{array}$ & $\begin{array}{l}\text { Systematic literature review of } \\
\text { English-language publications } \\
\text { 2000-2013 (academic focus) }\end{array}$ & $\begin{array}{l}\text { - 'Six main roles for librarians were identified: } \\
\text { librarian as teacher, technology specialist, } \\
\text { embedded librarian, information consultant, } \\
\text { knowledge manager, and subject librarian’ (p. 52). }\end{array}$ \\
\hline $\begin{array}{l}\text { Weng \& Ackerman } \\
\text { (2017) }\end{array}$ & $\begin{array}{l}\text { Survey of } 586 \text { public services } \\
\text { and technical services } \\
\text { librarians from professional } \\
\text { discussion lists (39\% public } \\
\text { services and } 61 \% \text { technical } \\
\text { services) }\end{array}$ & $\begin{array}{l}\text { - Librarians in the two areas experienced a feeling of } \\
\text { competition and an aggregate perception of } \\
\text { technical services work as playing a subordinate or } \\
\text { support role. } \\
\text { - Confirmed that both public services and technical } \\
\text { services perceive that public services librarians } \\
\text { have negative perceptions of technical services } \\
\text { librarians. } \\
\text { - } 97 \% \text { of both public services and technical services } \\
\text { groups saw technical services as having a direct } \\
\text { impact on library users (p. 204). }\end{array}$ \\
\hline
\end{tabular}


Table 6. Academic librarian perceptions of duties and roles of specific types of librarians, and/or related findings

\begin{tabular}{|c|c|c|}
\hline \multicolumn{3}{|c|}{ Librarian specialities } \\
\hline $\begin{array}{l}\text { Ochola \& } \\
\text { Jones } \\
\text { (2001) }\end{array}$ & $\begin{array}{l}\text { Survey of } 12 \text { liaison } \\
\text { librarians and } 30 \\
\text { departmental faculty at } \\
\text { a large, 4-year } \\
\text { institution }\end{array}$ & $\begin{array}{l}\text { - Librarian liaisons ranked the following as the top services they } \\
\text { provided: 1) Update the department on services, 2) Inform the } \\
\text { department of changes in the library, 3) Current awareness service to } \\
\text { faculty, 4) Library orientation to new faculty, 5) Select books and } \\
\text { serials, 6) Serve as research consultant to graduate students, 7) } \\
\text { Bibliographic instruction for undergraduates, 8) Offer library } \\
\text { resources seminars to faculty (Table } 1) \text {. } \\
\text { - } 67 \% \text { of librarians had not met with their department liaison faculty } \\
\text { within } 6 \text { months (p. } 36) \text {. } \\
\text { - The amount of time librarians spent on liaison duties varied widely, } \\
\text { from zero }(n=4) \text { to more than six hours (n=2) (p. 38). }\end{array}$ \\
\hline $\begin{array}{l}\text { Chapman } \\
\text { (2007) }\end{array}$ & $\begin{array}{l}\text { Comparison of } \\
\text { metadata job ads 2001- } \\
2006 \text { from } 7 \text { institutions }\end{array}$ & $\begin{array}{l}\text { Identified four roles for metadata librarians: collaboration, research, } \\
\text { education, and development. }\end{array}$ \\
\hline $\begin{array}{l}\text { Goetsch } \\
\text { (2008) }\end{array}$ & $\begin{array}{l}\text { Comparison of job ads } \\
\text { from 1995, 2000, and } \\
2005 \text { regarding library } \\
\text { skills }\end{array}$ & $\begin{array}{l}\text { - Identified growth of licensing, contract negotiation, and knowledge } \\
\text { management functions. } \\
\text { - Virtual reference skills, systems integration skills, scholarly } \\
\text { communication knowledge, and curation of local resources all moved } \\
\text { to core responsibilities or positions from } 1995 \text { to } 2005 \text {. } \\
\text { - Collection development is transforming to address shared and unique } \\
\text { local collections. } \\
\text { - Information services is growing to address social media. }\end{array}$ \\
\hline $\begin{array}{l}\text { Park \& Lu } \\
(2009)\end{array}$ & $\begin{array}{l}\text { Comparison of } \\
\text { metadata librarian job } \\
\text { ads posted to } \\
\text { AUTOCAT, 2003-2006 }\end{array}$ & $\begin{array}{l}\text { - Responsibilities found in over 50\% of cases (in ranked order) were } \\
\text { metadata creation, management (personnel), cataloguing, e-resources } \\
\text { management, and awareness of trends (p. 153). }\end{array}$ \\
\hline $\begin{array}{l}\text { Arendt \& } \\
\text { Lotts } \\
\text { (2012) }\end{array}$ & $\begin{array}{l}\text { Survey of } 354 \\
\text { librarians and } 140 \\
\text { departmental faculty at } \\
\text { multiple large, 4-year } \\
\text { institutions }\end{array}$ & $\begin{array}{l}\text { - Most commonly cited responsibilities: collection development was } \\
\text { the most commonly cited responsibility (96\%), followed by } \\
\text { instruction (87\%) and reference (83\%). } \\
\text { - Fewer than half reported performing these services in the past year: } \\
\text { teaching library resource workshops, consulting faculty about } \\
\text { curriculum integration, attending department functions, and notifying } \\
\text { faculty about new publications. }\end{array}$ \\
\hline Cox (2016) & $\begin{array}{l}\text { Literature review } \\
\text { concerning digital } \\
\text { scholarship }\end{array}$ & $\begin{array}{l}\text { Roles in digital scholarship include digital preservation, metadata } \\
\text { creation and enhancement, assignment of identifiers, hosting digital } \\
\text { collections, publishing journals, dissemination of open access } \\
\text { research and learning materials, managing research data, curation of } \\
\text { born-digital, advising on copyright, digital rights, and standards, text } \\
\text { mining, data analysis, geographic information systems, and provision } \\
\text { of spaces, tools, equipment, and training (p. 133). }\end{array}$ \\
\hline
\end{tabular}


Table 7. Academic librarian perceptions concerning academic librarians as teachers

\begin{tabular}{|c|c|c|}
\hline Citation & Study method & Core / primary duties / roles of academic librarians \\
\hline $\begin{array}{l}\text { Feldman \& } \\
\text { Sciamarella (2000 }\end{array}$ & $\begin{array}{l}\text { Survey of } 157 \text { faculty and } 52 \\
\text { librarians at six community } \\
\text { colleges }\end{array}$ & $\begin{array}{l}\text { - } 80 \% \text { of librarians felt their nonteaching status was } \\
\text { inappropriate. } \\
\text { - } 84 \% \text { felt being recognized as teaching faculty } \\
\text { would help improve librarian status in the } \\
\text { academic community (p. 492). }\end{array}$ \\
\hline $\begin{array}{l}\text { Tennant, Cataldo, } \\
\text { Sherwill-Navarro, \& } \\
\text { Jesano (2006) }\end{array}$ & $\begin{array}{l}\text { Liaison program satisfaction } \\
\text { survey of } 10 \text { liaisons at a large, } \\
\text { 4-year institution }\end{array}$ & $\begin{array}{l}\text { - Librarians found instruction to faculty (e.g., at } \\
\text { faculty meetings) and course-integrated instruction } \\
\text { to have the most impact on the success of their } \\
\text { liaison program. } \\
\text { - Respondents listed course-integrated instruction as } \\
\text { one of their most preferred duties (p. 407). }\end{array}$ \\
\hline Hall (2013) & $\begin{array}{l}\text { Surveyed } 188 \text { supervisors of } \\
216 \text { academic/research job } \\
\text { postings on ALA JobsList in } \\
2009 \text { that listed instruction } \\
\text { duties }\end{array}$ & $\begin{array}{l}\text { - } 87 \% \text { said instruction was very important to the } \\
\text { library (p. 28). } \\
\text { - One-shot sessions dominated the types of } \\
\text { instructional activities expected (> 90\%), though } \\
\text { teaching credit-bearing IL courses were } \\
\text { increasingly required (nearly 25\%) (Figure 4). } \\
\text { - } 30 \% \text { had a formal in-house training program for } \\
\text { instruction librarians (p. 31). } \\
\text { - } 96 \% \text { said instruction skills should be taught in } \\
\text { library schools (p. 33). }\end{array}$ \\
\hline Davis (2007) & $\begin{array}{l}\text { ILI-I listserv survey (n=382) } \\
\text { about library anxiety }\end{array}$ & $\begin{array}{l}\text { Even if they chose the profession of librarianship } \\
\text { for reasons other than teaching, many look forward } \\
\text { to the activity. However, } 25-35 \% \text { of respondents } \\
\text { do not enjoy teaching; } 63 \% \text { reported that } \\
\text { nervousness was their primary feeling right before } \\
\text { teaching; and } 60 \% \text { reported experiencing physical } \\
\text { symptoms of anxiety such as sweating and upset } \\
\text { stomach. }\end{array}$ \\
\hline Walter (2008) & $\begin{array}{l}\text { Six librarians interviewed at a } \\
\text { 'doctoral/research—extensive } \\
\text { institution' }\end{array}$ & $\begin{array}{l}\text { - Teaching has not been part of formal education, as } \\
\text { noted by a series of studies over the past } 25 \text { years } \\
\text { (p. 56). } \\
\text { - Interviewees 'identified strongly with the role of } \\
\text { librarian as teacher and sought out positions where } \\
\text { that role was valued,' and considered their job } \\
\text { titles immaterial to whether they pursued the } \\
\text { opportunity to teach (p. } 61 \text { ). }\end{array}$ \\
\hline LJ/Gale (2015) & $\begin{array}{l}\text { Survey of } 547 \text { faculty from } \\
\text { 'Gale’s faculty list' and } 499 \\
\text { librarians from 'a Library } \\
\text { Journal list' }\end{array}$ & $\begin{array}{l}\text { - 'Faculty in certain disciplines should teach their } \\
\text { students information literacy skills themselves' (p. } \\
\text { 41). }\end{array}$ \\
\hline $\begin{array}{l}\text { Vassilakaki \& } \\
\text { Moniarou- } \\
\text { Papaconstantinou } \\
(2015)\end{array}$ & $\begin{array}{l}\text { Systematic literature review of } \\
\text { librarians' roles, English- } \\
\text { language publications 2000- } \\
2014\end{array}$ & $\begin{array}{l}\text { - Information professionals described themselves as } \\
\text { assuming 'a range of responsibilities associated } \\
\text { with teaching and learning' (p. 41). }\end{array}$ \\
\hline
\end{tabular}


Table 8. Findings concerning librarian and faculty perceptions of faculty status

\begin{tabular}{|c|c|c|}
\hline Citation & Study method & Findings \\
\hline \multicolumn{3}{|c|}{ Librarian perceptions } \\
\hline $\begin{array}{l}\text { Thompson } \\
\text { (2014) }\end{array}$ & $\begin{array}{l}\text { Literature review concerning } \\
\text { librarian perceptions }\end{array}$ & $\begin{array}{l}\text { - Asserts the centrality of librarians' role in academic } \\
\text { missions with elevating the status of librarians in the } \\
\text { minds of other faculty. } \\
\text { - The arguments against faculty status for librarians } \\
\text { include additional pressure and the belief that tenure and } \\
\text { faculty status are unimportant. } \\
\text { - Cites one study that found librarians' tenure 'could } \\
\text { partially predict the quality of an institution (Meyer, } \\
\text { 1999); and another which found the opposite (Bolger \& } \\
\text { Smith, 2006)' (p. 38). }\end{array}$ \\
\hline $\begin{array}{l}\text { Galbraith, } \\
\text { Garrison, and } \\
\text { Hales (2016) }\end{array}$ & $\begin{array}{l}\text { Survey of } 719 \text { librarians } \\
\text { with faculty and non-faculty } \\
\text { status at } 25 \text { ARL libraries }\end{array}$ & $\begin{array}{l}\text { - Both faculty and non-faculty librarians at ARL libraries } \\
\text { agree that administrators listen more attentively when } \\
\text { librarians have faculty status. } \\
\text { - Faculty status empowers librarians to more actively } \\
\text { participate in campus governance and policymaking, thus } \\
\text { promoting collaboration with non-librarian faculty. }\end{array}$ \\
\hline \multicolumn{3}{|c|}{ Faculty perceptions } \\
\hline $\begin{array}{l}\text { Weng \& Murray } \\
\text { (2019) }\end{array}$ & $\begin{array}{l}\text { Survey of } 505 \text { non-librarian } \\
\text { faculty at four 4-year } \\
\text { institutions }\end{array}$ & $\begin{array}{l}\text { - Most faculty at three of the institutions knew whether the } \\
\text { librarians had faculty status. } \\
\text { - Noticeably higher percentages of faculty at the two } \\
\text { institutions granting faculty status to librarians were } \\
\text { pleased with their librarians' faculty status (66\% and } \\
\text { 49\%) (p. 205). } \\
\text { - Researchers concluded that faculty status for librarians } \\
\text { 'not only accorded better visibility to librarians but } \\
\text { elicited from some respondents an expression of } \\
\text { solidarity' (p. 206). } \\
\text { - Faculty status of librarians does not necessarily enhance } \\
\text { perceptions of quality among faculty. } \\
\text { - No noticeable difference was found in non-librarian } \\
\text { faculty perceptions of librarians at institutions that } \\
\text { granted faculty status to librarians than at those who did } \\
\text { not (p. 205). }\end{array}$ \\
\hline
\end{tabular}


Table 9. Academic librarian perceptions of motivations and affective behaviors of librarians

\begin{tabular}{|c|c|c|}
\hline Citation & Study method & Findings \\
\hline $\begin{array}{l}\text { Ard et al. } \\
(2006)\end{array}$ & Survey of 96 MLIS students & $\begin{array}{l}\text { - Found the job functions of librarianship to be the major } \\
\text { incentive for choosing the profession. The second-ranked } \\
\text { motivation was another person’s recommendation. } \\
\text { Compensation was listed as a major influence by } 24 \% \text { (p. } \\
\text { 241). 'Love of books,' was selected by only } 2 \% \text { of their } \\
\text { respondents. } \\
\text { - Of seven anticipated salary ranges given, more respondents } \\
\text { selected a response below } \$ 34,999 \text { (55\%) than above this } \\
\text { level (p. 242). }\end{array}$ \\
\hline $\begin{array}{l}\text { Davis } \\
\text { (2007) }\end{array}$ & $\begin{array}{l}\text { ILI-I listserv survey }(\mathrm{n}=382) \\
\text { about library anxiety }\end{array}$ & $\begin{array}{l}\text { - Academic librarians are bothered by stereotypes, either } \\
\text { completely (17\%) or 'to a certain degree' (38\%). } \\
\text { - The top reason for choosing librarianship was a desire to } \\
\text { help people (64\%), followed by love of reading and literacy } \\
\text { (52\%) (p. } 85) \text {. } \\
\text { - Just less than half of the } 382 \text { academic librarians definitely } \\
\text { did not plan to change careers. }\end{array}$ \\
\hline $\begin{array}{l}\text { Davis- } \\
\text { Kendrick } \\
(2009)\end{array}$ & $\begin{array}{l}\text { Survey of African-American } \\
\text { male librarians from public, } \\
\text { academic, and special libraries } \\
(\mathrm{n}=93)\end{array}$ & $\begin{array}{l}\text { - } 61 \% \text { said they were not bothered by male librarian } \\
\text { stereotypes, but of those who were, both heterosexual and } \\
\text { homosexual participants were bothered by the sexuality } \\
\text { stereotypes placed on male librarians (p. 39). } \\
\text { - } 53 \% \text { indicated they became a librarian to 'help people or be } \\
\text { in a service-oriented career,' while many did so because of a } \\
\text { love for teaching (48\%) and research (47\%). Additional } \\
\text { reasons were enjoying technology (40\%), willingness to } \\
\text { positively impact the community (38\%) and being a role } \\
\text { model for African-American youth (32\%) (p. 37). } \\
\text { 59\% indicated it was unlikely they would change careers, } \\
\text { due to enjoying learning (83\%), being in a service profession } \\
\text { (80\%), and being professionally active (74\%). }\end{array}$ \\
\hline $\begin{array}{l}\text { Goetsch } \\
(2008)\end{array}$ & $\begin{array}{l}\text { Comparison of academic } \\
\text { librarian job ads from } 1995 \text {, } \\
2000 \text {, and } 2005\end{array}$ & $\begin{array}{l}\text { - Found themes of adaptability, sound professional values, } \\
\text { creativity, and tolerance for ambiguity (pp. 170-171). }\end{array}$ \\
\hline $\begin{array}{l}\text { Arendt \& } \\
\text { Lotts }(2012)\end{array}$ & $\begin{array}{l}\text { Survey of } 354 \text { librarians and } \\
140 \text { departmental faculty at } \\
\text { multiple large, 4-year } \\
\text { institutions about liaison } \\
\text { librarians }\end{array}$ & $\begin{array}{l}\text { - The majority of liaisons describe themselves as successful } \\
\text { (63\%) or very successful (13.8\%), while } 63 \% \text { are satisfied or } \\
\text { very satisfied (p. } 162) \text {. }\end{array}$ \\
\hline $\begin{array}{l}\text { Butler \& } \\
\text { Byrd (2016) }\end{array}$ & $\begin{array}{l}\text { Survey of } 80 \text { pairs of students } \\
\text { and librarians who engaged in } \\
\text { research consultations at a } \\
\text { large university }\end{array}$ & $\begin{array}{l}\text { - In } 23 \text { cases librarians predicted students would say the } \\
\text { encounter was 'Somewhat Useful,' but students rated it as } \\
\text { 'Very Useful' } 76 \% \text { of the time (Figure } 1 \text { ). In these } \\
\text { encounters, students reported discussing } 3.48 \text { resource types, } \\
\text { while the librarians reported only } 2.13 \text { (p. 85). }\end{array}$ \\
\hline $\begin{array}{l}\text { Weng \& } \\
\text { Ackerman } \\
\text { (2017) }\end{array}$ & $\begin{array}{l}\text { Survey of } 586 \text { public services } \\
\text { and technical services } \\
\text { librarians from professional } \\
\text { discussion lists (39\% public }\end{array}$ & $\begin{array}{l}\text { Public and technical services should possess the qualities } \\
\text { responsiveness to change, user-centred philosophy, } \\
\text { collaborative nature, adaptability to technologies, forward- } \\
\text { thinking, and motivation to start new initiatives or respond } \\
\text { proactively (pp. 201-202). }\end{array}$ \\
\hline
\end{tabular}




\begin{tabular}{|l|l|l|}
\hline & $\begin{array}{l}\text { services and 61\% technical } \\
\text { services) }\end{array}$ & $\begin{array}{l}\text { Additional qualities: ‘communication and interpersonal } \\
\text { skills' was listed most often for public services librarians, } \\
\text { and 'creativity, flexibility, problem-solving' was listed most } \\
\text { often for technical services librarians (and as No. } 2 \text { for } \\
\text { additional public services qualities) (p. 202). }\end{array}$ \\
& & \\
\hline
\end{tabular}

Table 10. Faculty value for librarian skills and knowledge

\begin{tabular}{|c|c|c|}
\hline Citation & Study method & Findings \\
\hline $\begin{array}{l}\text { Feldman \& } \\
\text { Sciammarella } \\
\text { (2000) }\end{array}$ & $\begin{array}{l}\text { Survey of } 157 \text { faculty } \\
\text { and } 52 \text { librarians at six } \\
\text { community colleges }\end{array}$ & $\begin{array}{l}\text { - } 82 \% \text { of faculty felt their librarian was able to assist them in } \\
\text { gathering information for research } \\
\text { - } 69 \% \text { said they had contacted a librarian regarding their own } \\
\text { research or that of their students (p. 496). }\end{array}$ \\
\hline Jeffries (2000) & 21 faculty interviews & $\begin{array}{l}\text { - Faculty value librarians' expertise in information services. } \\
\text { - } 76 \% \text { said they would value librarian help in developing or } \\
\text { revising effective assignments (p. 122). }\end{array}$ \\
\hline Yang (2000) & $\begin{array}{l}\text { Survey of } 42 \text { faculty at a } \\
\text { large } 4 \text {-year institution }\end{array}$ & $\begin{array}{l}\text { A large majority (89\%) of liberal arts faculty found subject } \\
\text { background indispensable; but a similarly high proportion of } \\
\text { science faculty (86\%) did not. }\end{array}$ \\
\hline $\begin{array}{l}\text { Ducas \& } \\
\text { Michaud- } \\
\text { Oystryk (2003) }\end{array}$ & $\begin{array}{l}\text { Survey of } 734 \text { full-time } \\
\text { faculty at a large, 4-year } \\
\text { university about the } \\
\text { librarian-faculty } \\
\text { relationship }\end{array}$ & $\begin{array}{l}\text { - In response to a survey about the librarian-faculty relationship, } \\
734 \text { full-time faculty at one large, 4-year university ranked } \\
\text { librarian work in the area of information services most highly } \\
\text { (84\% said it was 'important' or 'very important'), followed by } \\
\text { collections (80\%), information technology (69\%), research } \\
\text { (60\%), and instruction (50\%) (p. 71). }\end{array}$ \\
\hline $\begin{array}{l}\text { Manuel, Beck, } \\
\text { \& Molloy } \\
(2005)\end{array}$ & $\begin{array}{l}\text { Interviews of } 21 \text { faculty } \\
\text { at a large, 4-year } \\
\text { institution considered to } \\
\text { be heavy library } \\
\text { instruction users }\end{array}$ & $\begin{array}{l}\text { - Almost half their interviewed faculty (who were heavy users of } \\
\text { library instruction) mentioned library instruction was valuable } \\
\text { for keeping their own skills up-to-date (p. 148). } \\
\text { - One study suggests this characteristic might be more valued by } \\
\text { social science and science faculty than humanities faculty (p. } \\
\text { 154). }\end{array}$ \\
\hline $\begin{array}{l}\text { Wu \& Kendall } \\
\text { (2006) }\end{array}$ & $\begin{array}{l}\text { Survey of } 61 \text { business } \\
\text { faculty at } 16 \text { campuses } \\
\text { of a large state } \\
\text { university system }\end{array}$ & $\begin{array}{l}\text { - Faculty perceive librarians as skilled in creating bibliographies, } \\
\text { web pages, and slideshow presentations about sources, topics, } \\
\text { and updates on new tools. } \\
\text { - 93\% of the } 61 \text { respondents had worked with a librarian, } 79 \% \\
\text { had requested library instruction, and 56\% referred students to } \\
\text { librarians for help with projects (p. 91). }\end{array}$ \\
\hline $\begin{array}{l}\text { Weng \& Murray } \\
\text { (2019) }\end{array}$ & $\begin{array}{l}\text { Survey of } 505 \text { non- } \\
\text { librarian faculty at four } \\
4 \text {-year institutions }\end{array}$ & $\begin{array}{l}\text { - Many faculty said librarian assistance with their own research } \\
\text { was critical (25\%) or helpful (60\%) (p. 208). }\end{array}$ \\
\hline
\end{tabular}


Table 11. Faculty perceptions of academic librarians as teachers

\begin{tabular}{|c|c|c|}
\hline Citation & Study method & Findings \\
\hline $\begin{array}{l}\text { Feldman \& } \\
\text { Sciammarella } \\
\text { (2000) }\end{array}$ & $\begin{array}{l}\text { Survey of } 157 \text { faculty and } 52 \\
\text { librarians at six community } \\
\text { colleges }\end{array}$ & $\begin{array}{l}\text { - } 36 \% \text { of community college faculty used instruction } \\
\text { (p. 494). }\end{array}$ \\
\hline Yang (2000) & $\begin{array}{l}\text { Survey of } 42 \text { faculty at a large } 4- \\
\text { year institution }\end{array}$ & $\begin{array}{l}\text { - More faculty rated instruction as 'not important' } \\
\text { than 'very important' (pp. 125-126), }\end{array}$ \\
\hline Gonzales (2001) & $\begin{array}{l}\text { Survey of } 44 \text { faculty at a } \\
\text { medium-sized, 4-year institution }\end{array}$ & $\begin{array}{l}\text { - } 43 \% \text { of faculty had requested library instruction (p. } \\
\text { 13). Of those 19, almost } 90 \% \text { found it useful. }\end{array}$ \\
\hline $\begin{array}{l}\text { Ochola \& Jones } \\
\text { (2001) }\end{array}$ & $\begin{array}{l}\text { Survey of } 12 \text { liaison librarians } \\
\text { and } 30 \text { departmental faculty at a } \\
\text { large, 4-year institution }\end{array}$ & $\begin{array}{l}\text { - Found that almost as many of their } 30 \text { faculty rated it } \\
\text { as 'minimally important' or 'not important' as those } \\
\text { who rated it 'very important' or 'important' (p. 35). }\end{array}$ \\
\hline $\begin{array}{l}\text { Ducas \& } \\
\text { Michaud-Oystryk } \\
\text { (2003) }\end{array}$ & $\begin{array}{l}\text { Survey of } 734 \text { full-time faculty } \\
\text { at a large, } 4 \text {-year university } \\
\text { about the librarian-faculty } \\
\text { relationship }\end{array}$ & $\begin{array}{l}\text { - } 41 \% \text { of the humanities, social sciences, and health } \\
\text { sciences faculty thought librarians' teaching had a } \\
\text { substantial or very substantial impact, versus only } \\
24 \% \text { of the pure and applied sciences faculty (p. 67). }\end{array}$ \\
\hline $\begin{array}{l}\text { Wu \& Kendall } \\
\text { (2006) }\end{array}$ & $\begin{array}{l}\text { Survey of } 61 \text { business faculty at } \\
16 \text { campuses of a large state } \\
\text { university system }\end{array}$ & $\begin{array}{l}\text { - } 79 \% \text { of } 81 \text { business faculty requested library } \\
\text { instruction and } 56 \% \text { of them referred students to } \\
\text { librarians for help with projects (p. 91). }\end{array}$ \\
\hline Bury (2011) & $\begin{array}{l}\text { Survey of } 221 \text { faculty at a large, } \\
\text { 4-year university }\end{array}$ & $\begin{array}{l}\text { - } 53 \% \text { used library instruction (p. 54). } \\
\text { - } 68.1 \% \text { of female faculty ‘incorporate library } \\
\text { instruction’ into classes. } \\
\text { - } 38.4 \% \text { of male faculty ‘incorporate library } \\
\text { instruction’ into classes (p. 55). }\end{array}$ \\
\hline $\begin{array}{l}\text { Arendt \& Lotts } \\
\text { (2012) }\end{array}$ & $\begin{array}{l}\text { Survey of } 354 \text { librarians and } 140 \\
\text { departmental faculty at multiple } \\
\text { large, 4-year institutions about } \\
\text { liaison librarians }\end{array}$ & $\begin{array}{l}\text { - Librarians considered library instruction and } \\
\text { discussing curriculum integration much more } \\
\text { important than faculty did. }\end{array}$ \\
\hline Saunders (2012) & $\begin{array}{l}\text { Survey of } 278 \text { faculty at } 50 \\
\text { random institutions across the } \\
\text { United States }\end{array}$ & $\begin{array}{l}\text { - } 71.8 \% \text { strongly agreed IL is important for their } \\
\text { students (p. 228). } \\
\text { - } 77.6 \% \text { strongly agreed or agreed they address IL in } \\
\text { their teaching } \\
\text { - High percentages (numbers not given) agreed or } \\
\text { strongly agreed teaching faculty and librarians were } \\
\text { responsible for teaching IL (p. 229). } \\
\text { - No correlation was found between discipline and } \\
\text { perceptions on teaching responsibilities for IL or } \\
\text { effectiveness of library instruction. } \\
\text { - A strong correlation was found between discipline } \\
\text { and instructional request frequency. }\end{array}$ \\
\hline Stanger (2012) & $\begin{array}{l}\text { Survey of } 14 \text { psychology faculty } \\
\text { at a large, 4-year institution }\end{array}$ & $\begin{array}{l}\text { - } 50 \text { \% or more thought it was of great or very great } \\
\text { importance for librarians to be involved in five of } \\
\text { the } 11 \text { performance indicators (p. 120). } \\
\text { - More than } 50 \text { percent of the faculty thought their } \\
\text { own role was important or very important in } \\
\text { developing } 10 \text { of the } 11 \text { IL indicators (p. 122). } \\
\text { - More than } 50 \text { percent of the faculty thought the } \\
\text { librarian's role was important or very important in } \\
\text { developing } 5 \text { of the } 11 \text { IL indicators (p.123). }\end{array}$ \\
\hline
\end{tabular}




\begin{tabular}{|c|c|c|}
\hline & & $\begin{array}{l}\text { Faculty valued their role more highly than the role of } \\
\text { librarians for } 9 \text { of the } 11 \text { IL indicators (p. 123). }\end{array}$ \\
\hline LJ/Gale (2015) & $\begin{array}{l}\text { Survey of } 547 \text { faculty from } \\
\text { 'Gale’s faculty list' and } 499 \\
\text { librarians from 'a Library } \\
\text { Journal list' }\end{array}$ & $\begin{array}{l}\text { - } 28 \% \text { of faculty said they used librarians to teach IL } \\
\text { - } 51 \% \text { said they covered it themselves (p. 23). } \\
\text { - } 51 \% \text { of faculty said it was 'very essential' for their } \\
\text { campus library to provide IL instruction, with an } \\
\text { additional 34\% saying it was 'essential' (p. 17). }\end{array}$ \\
\hline $\begin{array}{l}\text { Weng \& Murray } \\
\text { (2019) }\end{array}$ & $\begin{array}{l}\text { Survey of } 505 \text { non-librarian } \\
\text { faculty at four 4-year institutions }\end{array}$ & $\begin{array}{l}\text { - } 45 \% \text { of faculty respondents requested instruction (p. } \\
\text { 203). } \\
\text { - } 77 \% \text { of faculty rated librarian teaching as 'very } \\
\text { important' or 'important' to the institution. } \\
\text { - } 20 \% \text { reported librarian teaching was 'critical' to } \\
\text { themselves individually, and 60\% reported it was } \\
\text { 'helpful' to them individually (p. 208). }\end{array}$ \\
\hline
\end{tabular}


Table 12. Student perceptions of academic librarians' knowledge and skills

\begin{tabular}{|c|c|c|}
\hline Citation & Study method & Findings \\
\hline $\begin{array}{l}\text { Hernon \& } \\
\text { Pastine } \\
\text { (1977) }\end{array}$ & $\begin{array}{l}\text { Survey of } 362 \text { full-time } \\
\text { students at a large, } 4 \text {-year } \\
\text { institution }\end{array}$ & $\begin{array}{l}\text { - Instead of viewing academic librarians as ‘educated' or } \\
\text { 'professional,' students saw them as ‘trained' or ‘skilled' and } \\
\text { were largely unable to distinguish between the roles of } \\
\text { librarians and library staff (p. 132). } \\
\text { - Students emphasized the value of librarians' skills in finding } \\
\text { materials rather than in how to use materials. } \\
\text { - Only 31.6\% of Hernon and Pastine's students indicated that } \\
\text { their interactions with librarians could be considered a } \\
\text { learning experience ‘frequently' or 'always' (p. 136). }\end{array}$ \\
\hline $\begin{array}{l}\text { Fagan } \\
(2003)\end{array}$ & $\begin{array}{l}\text { Survey of } 48 \text { undergraduates } \\
\text { at a large, } 4 \text {-year university }\end{array}$ & $\begin{array}{l}\text { - } 15 \% \text { of students knew that a master's degree was required to } \\
\text { be a librarian (p. 135). } \\
\text { - Students emphasized the value of librarians' skills in finding } \\
\text { materials rather than in how to use materials. } \\
\text { - When asked what job responsibilities librarians performed } \\
\text { regularly, student respondents listed these most often: } \\
\text { technical activities, reference, and cataloguing/organizing } \\
\text { tasks. }\end{array}$ \\
\hline $\begin{array}{l}\text { Luzius \& } \\
\text { Noe (2003) }\end{array}$ & $\begin{array}{l}\text { Survey of } 94 \text { students from } \\
\text { six undergraduate } \\
\text { composition classes at a } \\
\text { large, 4-year university }\end{array}$ & $\begin{array}{l}\text { - } 68 \% \text { percent of students thought only a bachelor's degree was } \\
\text { needed to be a librarian, 22\% indicated that a high school } \\
\text { degree was sufficient, and only } 10 \% \text { knew that the profession } \\
\text { required a master's degree (p. 14). Fewer than half classified } \\
\text { librarians as faculty (p. 14). }\end{array}$ \\
\hline $\begin{array}{l}\text { Stanley } \\
(2007)\end{array}$ & $\begin{array}{l}\text { Focus groups with } 15 \\
\text { minority undergraduates at a } \\
\text { large 4-year institution }\end{array}$ & $\begin{array}{l}\text { - Students were unsure of educational requirements or what } \\
\text { career paths were available in the information sciences (p. } \\
\text { 85). }\end{array}$ \\
\hline $\begin{array}{l}\text { Martin \& } \\
\text { Park (2011) }\end{array}$ & $\begin{array}{l}\text { Survey of } 76 \text { students in three } \\
\text { classes at a large, } 4 \text {-year } \\
\text { institution }\end{array}$ & $\begin{array}{l}\text { - Found that reference consultations improved students' views } \\
\text { toward librarian skills (p. 37). }\end{array}$ \\
\hline $\begin{array}{l}\text { Meredith \& } \\
\text { Mussel } \\
\text { (2014) }\end{array}$ & $\begin{array}{l}\text { Survey of } 47 \text { graduate and } \\
\text { undergraduate students given } \\
\text { in } 11 \text { online courses with an } \\
\text { embedded librarian at a } \\
\text { small, 4-year university }\end{array}$ & $\begin{array}{l}\text { - 'Figuring out how to narrow your search results' was the top } \\
\text { area improved by librarian tips and forum discussion, } \\
\text { followed very closely by 'figuring out which are the best } \\
\text { search tools to use for your topic.' } \\
\text { - } 46 \% \text { reported their abilities were 'greatly improved,' and 39\% } \\
\text { reported 'improved' (p. 98). }\end{array}$ \\
\hline $\begin{array}{l}\text { Jameson, } \\
\text { Natal, \& } \\
\text { Napp } \\
(2019)\end{array}$ & $\begin{array}{l}\text { Survey of } 235 \text { undergraduate } \\
\text { and graduate students at a } \\
\text { large, 4-year institution }\end{array}$ & $\begin{array}{l}\text { - The top reason students asked a librarian for help was 'to } \\
\text { learn how to use a library resource' (48\%). Learning how to } \\
\text { use a library resource slightly outranked 'to get help finding } \\
\text { books' (46\%), and 'to get help finding articles' (33\%) (p. } \\
\text { 373). } \\
\text { - The top reason students didn't ask was they liked to figure } \\
\text { things out on their own (p. 372). } \\
\text { - There was a relationship between students who did not ask } \\
\text { librarians for help and } \\
\text { o those who said they could not identify librarians, } \\
\text { o those who said a librarian had not visited their classes (p. } \\
\text { 375). }\end{array}$ \\
\hline
\end{tabular}


Table 13. Student perceptions of academic librarians' duties and roles

\begin{tabular}{|c|c|c|}
\hline Citation & Study method & Findings \\
\hline $\begin{array}{l}\text { Jenkins } \\
\text { (2001) }\end{array}$ & $\begin{array}{l}\text { Surveys of } 201 \text { students (primarily } \\
\text { undergraduate) at a 4-year, medium- } \\
\text { sized university regarding the } \\
\text { responsibilities of reference } \\
\text { librarians }\end{array}$ & $\begin{array}{l}\text { - } 51 \% \text { of students said primary responsibility was to } \\
\text { direct patrons to resources. } \\
\text { - Only } 32.8 \% \text { selected all options on the survey, } \\
\text { including providing directions to resources and } \\
\text { spaces, answering research questions, and helping } \\
\text { with resources (p. 233). }\end{array}$ \\
\hline $\begin{array}{l}\text { Polger \& } \\
\text { Okamoto } \\
(2010)\end{array}$ & $\begin{array}{l}\text { Survey of } 500 \text { undergraduate and } \\
\text { graduate students at two large 4-year } \\
\text { institutions }\end{array}$ & $\begin{array}{l}\text { - Students generally perceived librarians’ professional } \\
\text { roles as caretakers of books, reference } \\
\text { assistants, and policy enforcers. }\end{array}$ \\
\hline $\begin{array}{l}\text { Magi \& } \\
\text { Mardeusz } \\
(2013)\end{array}$ & $\begin{array}{l}\text { Survey of undergraduate and } \\
\text { graduate students who had } \\
\text { participated in a consultation }(\mathrm{n}=51) \\
\text { at a large, 4-year institution }\end{array}$ & $\begin{array}{l}\text { - When students were asked 'What kinds of things did } \\
\text { the librarian try to help you with,', almost three- } \\
\text { quarters mentioned 'selecting and recommending } \\
\text { sources', while a third said 'librarian taught them how } \\
\text { to search' (p. 611). } \\
\text { - Some respondents also commented that the librarian } \\
\text { helped them understand assignments, clarify topics, } \\
\text { and develop a search strategy. } \\
\text { - Face-to-face consultations were valuable because of } \\
\text { their efficiency as compared to email or chat; in- } \\
\text { person interactions allowed them to watch the } \\
\text { librarian's search process; and because of the } \\
\text { interactive collaboration (p. 612). }\end{array}$ \\
\hline $\begin{array}{l}\text { O’Neill \& } \\
\text { Guilfoyle } \\
\text { (2015) }\end{array}$ & $\begin{array}{l}\text { Study concerning what to call the } \\
\text { Reference Services Department of } \\
182 \text { faculty and } 122 \text { undergraduate } \\
\text { and graduate students at a medium- } \\
\text { sized } 4 \text {-year university as well as } 21 \\
\text { staff and } 11 \text { community users }\end{array}$ & $\begin{array}{l}\text { - The most prevalent response (36.2\%) to the naming } \\
\text { question was 'help' followed by } \\
\text { 'research' (26.1\%) (p. 389). } \\
\text { - Across all three groups (faculty, graduate, and } \\
\text { undergraduate students), the assistance most often } \\
\text { sought was help finding books (p. 389). } \\
\text { - The authors speculated students might not have } \\
\text { understood that additional services were available (p. } \\
\text { 387). }\end{array}$ \\
\hline $\begin{array}{l}\text { Blake et al. } \\
\text { (2016) }\end{array}$ & $\begin{array}{l}\text { Web-based survey of } 381 \\
\text { undergraduate and graduate students, } \\
\text { faculty, clinicians, and residents at a } \\
\text { medium-sized, 4-year university in } \\
\text { the health sciences }\end{array}$ & $\begin{array}{l}\text { - Respondents valued the library's embedded librarian } \\
\text { program in health sciences for helping them } \\
\text { successfully complete assignments and } \\
\text { improved grades, progressing their research skills, and } \\
\text { improving research self-efficacy. } \\
\text { - A primary reason given for lack of use was } \\
\text { unawareness of the service and scope of assistance. } \\
\text { - Respondents indicated that more extensive marketing } \\
\text { of the program and increased presence within } \\
\text { departments would improve utilization. }\end{array}$ \\
\hline $\begin{array}{l}\text { Butler \& } \\
\text { Byrd } \\
\text { (2016) }\end{array}$ & $\begin{array}{l}\text { Survey of } 80 \text { pairs of students and } \\
\text { librarians who engaged in research } \\
\text { consultations at a large university }\end{array}$ & $\begin{array}{l}\text { - Students might perceive research consultations as } \\
\text { more valuable than librarians expect. }\end{array}$ \\
\hline
\end{tabular}


Table 14. Student perceptions of academic librarians’ motivations and affective behaviors

\begin{tabular}{|c|c|c|}
\hline Citation & Study method & Findings \\
\hline Stanley (2007) & $\begin{array}{l}\text { Focus groups with } 15 \\
\text { students }\end{array}$ & $\begin{array}{l}\text { - Students described their image of librarians as } \\
\text { 'shy,' 'organized,' 'helpful,' 'quiet,' and } \\
\text { 'reserved,' and as someone who 'reads a lot' and } \\
\text { 'someone who checks books in and out' (p. 85). }\end{array}$ \\
\hline $\begin{array}{l}\text { Fitzpatrick, Moore, \& } \\
\text { Lang (2008) }\end{array}$ & $\begin{array}{l}\text { Entrant survey study } \\
(\mathrm{n}=562) \text { of } \\
\text { undergraduates at a large, } \\
\text { 4-year university }\end{array}$ & $\begin{array}{l}\text { - When asked why they didn’t use a reference desk } \\
\text { staffed only by librarians, most students said they } \\
\text { just didn’t have a need, but } 21 \% \text { chose ‘scary' or } \\
\text { 'afraid' (p. 236). } \\
\text { - In a follow-up focus group (n=10) of 'more } \\
\text { experienced users,' librarians were described as } \\
\text { 'older, quieter, more 'official-looking', and 'like } \\
\text { they might know more' compared to staff at a } \\
\text { nearby learning commons desk, who were } \\
\text { described as 'younger, busier, less formal, less } \\
\text { patient, and more “techy”' (p. 236). }\end{array}$ \\
\hline $\begin{array}{l}\text { Bonnet } \\
\text { \& McAlexander (2013) }\end{array}$ & $\begin{array}{l}\text { Survey of undergraduate } \\
\text { students, graduate } \\
\text { students, and faculty/staff } \\
(\mathrm{n}=1,015) \text { at a large, } \\
\text { multi-campus, 4-year } \\
\text { university }\end{array}$ & $\begin{array}{l}\text { - Smiling and wearing a nametag improved the } \\
\text { approachability ratings for each } \\
\text { population surveyed. } \\
\text { - Images of librarians wearing blue shirts deemed } \\
\text { more approachable than those wearing white or red } \\
\text { (pp. 340-342). }\end{array}$ \\
\hline Magi \& Mardeusz (2013) & $\begin{array}{l}\text { Exploratory, qualitative } \\
\text { study of individual } \\
\text { research consultations }\end{array}$ & $\begin{array}{l}\text { - Students who had participated in face-to-face } \\
\text { consultations with a librarian 'appreciated being } \\
\text { reassured and inspired' and desired to build } \\
\text { personal relationships with librarians. } \\
\text { - Students also mentioned interacting with librarians } \\
\text { 'forced them to focus' and built their confidence } \\
\text { (p. 613). }\end{array}$ \\
\hline $\begin{array}{l}\text { Borchard, Wimberley, } \\
\text { Eng-Ziskin, \& } \\
\text { Fidgeon (2018) }\end{array}$ & $\begin{array}{l}\text { Showed online avatars to } \\
\text { students at a large, 4-year } \\
\text { Hispanic-serving } \\
\text { Institution }\end{array}$ & $\begin{array}{l}\text { A majority of the } 120 \text { participants did not visualise } \\
\text { librarians as elderly, frumpy, or unapproachable, } \\
\text { but might still associate them with certain } \\
\text { stereotypes, such as being female and wearing } \\
\text { glasses. } \\
\text { - Authors concluded that the pop culture image of } \\
\text { librarians did not influence student perceptions (p. } \\
\text { 48). }\end{array}$ \\
\hline $\begin{array}{l}\text { Jameson, Natal, \& Napp } \\
\text { (2019) }\end{array}$ & $\begin{array}{l}\text { Survey of } 235 \\
\text { undergraduate and } \\
\text { graduate students at a } \\
\text { large, 4-year institution }\end{array}$ & $\begin{array}{l}\text { - Students rated librarians as ‘very approachable’ or } \\
\text { 'approachable' } 79 \% \text { of the time, with } 16 \% \\
\text { choosing 'slightly approachable' (p. 375). } \\
\text { - } 62 \% \text { of students said they could tell which library } \\
\text { workers were librarians, but } 27 \% \text { said the ways } \\
\text { they identified librarians included 'anyone behind } \\
\text { the reference desk' and } 26 \% \text { included 'anyone } \\
\text { beyond the circulation desk.' } \\
\text { - 5\% of students said 'Only the people with library } \\
\text { degrees are librarians' (p. 374). } \\
\text { - Of the } 12 \text { of students who indicated librarians were } \\
\text { unapproachable, comments mentioned 'they look } \\
\text { busy' or too involved (p. 377). }\end{array}$ \\
\hline
\end{tabular}


Table 15. Variations in student perceptions of academic librarians' motivations and affective behaviors

\begin{tabular}{|c|c|c|}
\hline Citation & Study method & Findings \\
\hline Long (2011) & $\begin{array}{l}\text { Interviews with } 9 \text { Latino } \\
\text { undergraduate students at a large, } \\
\text { 4-year institution }\end{array}$ & $\begin{array}{l}\text { - Students experienced 'ambiguity and } \\
\text { confusion through their experiences with } \\
\text { academic libraries' (p. 510). } \\
\text { - Found barriers to utilisation in students' } \\
\text { perception of the library as a social and } \\
\text { cultural place and their uncertainty about the } \\
\text { purpose of the library/librarians. }\end{array}$ \\
\hline $\begin{array}{l}\text { Blundell \& Lambert } \\
\text { (2014) }\end{array}$ & $\begin{array}{l}\text { Survey of } 96 \text { second-semester } \\
\text { freshmen at a large, 4- } \\
\text { year university }\end{array}$ & $\begin{array}{l}\text { - 'Females were more likely to believe } \\
\text { reference librarians were unhelpful' (p. 266). } \\
\text { - 'Caucasians were more likely to believe } \\
\text { there is often no one available in the library } \\
\text { to help them' (p. 266). }\end{array}$ \\
\hline $\begin{array}{l}\text { Bonnet } \\
\text { \& McAlexander (2012) }\end{array}$ & $\begin{array}{l}\text { Survey with images of librarians; } \\
449 \text { respondents (undergraduate } \\
\text { students, graduate students, } \\
\text { faculty/staff) were asked to } \\
\text { evaluate their approachability }\end{array}$ & $\begin{array}{l}\text { - Female librarians were perceived as more } \\
\text { approachable and that respondents would } \\
\text { prefer to seek help from a librarian near their } \\
\text { age (p. 280). } \\
\text { - African-American respondents selected- } \\
\text { African Americans as more approachable, } \\
\text { white respondents stated no preference, and } \\
\text { Asian respondents rated African-American } \\
\text { librarians lower than white librarians (p. } \\
\text { 282). }\end{array}$ \\
\hline $\begin{array}{l}\text { Borelli, Su, Selden, \& } \\
\text { Munip (2018) }\end{array}$ & $\begin{array}{l}4 \text { focus groups with } 8 \text { first- } \\
\text { generation college students each, } \\
\text { two first-year and two upper- } \\
\text { division, at a large, 4-year } \\
\text { institution }\end{array}$ & $\begin{array}{l}\text { - Interactions with library personnel limited to } \\
\text { formal instruction and mandatory course } \\
\text { requirements. } \\
\text { - Interactions included directional, reference, } \\
\text { and IT-related. } \\
\text { - Interactions generally positive; negative } \\
\text { interactions were related to a perception the } \\
\text { library personnel involved was reluctant to } \\
\text { assist. } \\
\text { - Age of personnel relevant to perceptions of } \\
\text { interactions, with peer-to-peer interactions } \\
\text { perceived as more "in tune" but "adult" } \\
\text { personnel perceived as having more expertise } \\
\text { (p. 31). }\end{array}$ \\
\hline
\end{tabular}

